Review

\title{
Evaluation of Investments in Wind Energy Projects, under Uncertainty. State of the Art Review
}

\author{
Benjamin Murgas ${ }^{1, *}$, Alvin Henao ${ }^{2} \mathbb{D}$ and Luceny Guzman ${ }^{2}$ \\ 1 Administrative Planning Department, Gobernación de La Guajira, Riohacha 440001, Colombia \\ 2 Industrial Engineering Department, Universidad del Norte, Puerto Colombia 081007, Colombia; \\ henaoa@uninorte.edu.co (A.H.); lguzman@uninorte.edu.co (L.G.) \\ * Correspondence: n.murgas@laguajira.gov.co
}

Citation: Murgas, B.; Henao, A.; Guzman, L. Evaluation of Investments in Wind Energy Projects, under Uncertainty. State of the Art Review. Appl. Sci. 2021, 11, 10213. https://doi.org/10.3390/ app112110213

Academic Editor: Alberto Benato

Received: 1 September 2021

Accepted: 19 October 2021

Published: 31 October 2021

Publisher's Note: MDPI stays neutral with regard to jurisdictional claims in published maps and institutional affiliations.

Copyright: (c) 2021 by the authors. Licensee MDPI, Basel, Switzerland. This article is an open access article distributed under the terms and conditions of the Creative Commons Attribution (CC BY) license (https:// creativecommons.org/licenses/by/ $4.0 /)$.
Abstract: The use of renewable energy sources, especially wind energy, has been widely developed, mostly during the last decade. The main objective of the present study is to conduct a literature review focused on the evaluation under uncertainty of wind energy investment using the real options approach to find out whether public opposition (NIMBY projects) has been contemplated, and if so, what have been the flexible strategies applied for its intervention. Overall, 97 publications were analyzed, identifying 20 different models or approaches, which were grouped into eight categories: 1. Real options, 2. Optimization, 3. Stochastics, 4. Financial evaluation, 5. Probabilistic, 6. Estimation, 7. Numerical prediction, and 8 . Others. The real options approach, present in $32 \%$ of the studies, was the most popular. Twenty-eight types of uncertainties were identified, which were grouped, for better analysis, into nine categories. In total, $62.5 \%$ of the studies included the price of electricity as a source of uncertainty; $18.8 \%$, the velocity of wind; and $15.6 \%$, the feed-in rates-subsidy. Both random and non-random techniques were applied to assess the real options and to model the uncertainties. When evaluating real options, the Monte Carlo simulation technique was the most preferred, with $16(51.6 \%)$ applications, followed by non-randomized techniques, decision tree, and dynamic programming, with eight $(25.8 \%)$ applications each. There is a marked tendency to use stochastic processes to model uncertainty, particularly geometric Brownian motion, which was used in $61.3 \%$ (19) of the studies in the sample. When searching for "real options AND (nimby OR public opposition)", no study was found, which shows the possibility of developing research on this aspect to determine its impact on investments in wind energy projects.

Keywords: wind energy; investment appraisal; real options; uncertainty; NIMBY projects; public opposition

\section{Introduction}

Approximately $80 \%$ of the world's energy demand is met with fossil fuels (IEA, 2017a), causing two thirds of the global emissions of $\mathrm{CO}_{2}$ (https://www.un.org/es/chronicle/ article/el-papel-de-los-combustibles-fosiles-en-un-sistema-energetico-sostenible accessed on 19 June 2021).

According to the 2019 report from the International Energy Agency (IEA) (www.eia. gov / aeo accessed on 19 June 2021), world energy consumption is projected to increase by $46.9 \%$ in 2050, going from 620 billion BTUs, produced in 2018, to 911 billion BTUs. If the sources of energy were not changed, this would generate a greater demand for fossil fuels, increasing the emission of carbon dioxide $\left(\mathrm{CO}_{2}\right)$ affecting the levels of global warming and climate change, greatly risking the survival of humankind [1].

With the aim of promoting a sustainable future for the planet, global strategies been proposed, such as the 2030 Agenda, adopted by the United Nations General Assembly in September 2015, which included a global goal on sustainable energy [2]. In addition, the Paris agreement (2015) established the aim of keeping the global average temperature below $2{ }^{\circ} \mathrm{C}$ above pre-industrial levels, and to continue efforts to bring it to $1.5^{\circ} \mathrm{C}$ [3]. 
In 2020, the UN calls for urgent action to achieve zero net greenhouse gas (GHG) emissions by 2050, which involves more than 120 countries, that contribute more than half the global GDP, alongside thousands of companies and investors, cities, regions, and universities. Countries aligned with this goal currently represent two-thirds of the global economy, and 63\% of global greenhouse gas emissions. The list includes the United States, the European Union, Japan, South Korea, Canada, South Africa, and China, which have committed to meeting the target by 2060 [4]. Colombia, for its part, seeks to reduce nine million tons of $\mathrm{CO}_{2}$ by 2030 [5].

Regardless, tackling climate change and the high levels of greenhouse gas emissions continue to be priority problems, meriting urgent solutions on a global scale. This need increases the use of renewable energy sources as a replacement of fossil fuels and, therefore, makes them play an important role in shaping the energy matrix of the future [6-10].

Within renewable energies, wind energy is one of the fastest growing in the world. From 2011 to 2020, its production capacity increased from $220 \mathrm{GW}$ to $733 \mathrm{GW}, 233 \%$ [11]. However, to achieve the 2050 goal, annual increases in wind power capacity must reach $160 \mathrm{GW}$ in 2025, and rise to $280 \mathrm{GW}$ by 2030 , three times the level of 2020 , which would give renewable energies a participation of $60 \%$ in the world energy total, with $30 \%$ coming from wind and solar energy; meaning that it would require going from an investment of 380 billion dollars in 2020 to 1.6 trillion dollars by 2030, according to the IEA [4].

In addition, the growth and development of wind energy creates new challenges and opportunities due to: (i) a greater competitiveness of the energy sector [12-14], (ii) the discontinuity that characterizes the generation of wind energy $[15,16]$, (iii) the need to improve operations and maintenance [17,18], (iv) better conditions as required by the distribution system and grid integration [19,20], (v) the need for a wind energy regulation policy [21], and (vi) the environmental impact associated with power generation [22,23]. The barriers, which prevent a generalized use of wind energy, can be grouped into technological, economic, socio-political, and environmental dimensions, as shown in Table 1 [24].

Colombia projects large investments in wind energy generation, so these barriers can be increased. The areas with the greatest potential for wind energy (La Guajira Department-Upper Guajira region) are in areas that is are legally constituted as indigenous reservations (Decree 2164 [25]), inhabited by Wayuu communities, who act under their own traditions and customs, with total control over the property and use of the territory. In these regions, the communities are frequently opposed to interventions that affect their culture and customs. For these reasons, any type of project requires prior consultations (ILO Convention 169 of 1989, incorporated to Colombian legislation by Law 21 of 1991 [26]), making public opposition something of utmost importance.

This article attempts to review the literature regarding public opposition (NIMBY projects) to determine the flexible strategies implemented to overcome this type of barriers.

Public opposition can stop investment in wind energy generation projects and, consequently, affect their profitability.

Although there are strategies to manage public opposition by involving the communities from the beginning of the project, they may have uncertain behaviors or attitudes during the execution phase, despite planning their participation. We believe that a flexible approach to this type of uncertainty may be appropriate, so this research will explore real options to manage public opposition. Thus, this article is organized as such: the following section contains information on the general strategies used to overcome public opposition in investment projects. Section 3 describes the methodology used to review the state of the art on real options as applied to face different sources of uncertainty. Section 4 shows the results and analyzes them. In particular, Section 4.2 focuses on the uncertainties explored in the articles under the real options approach, and Section 4.4 analyzes public opposition under the same approach, to identify whether public opposition has been considered as uncertainty. Section 5 discusses these results and, finally, the last section shows the conclusions of this article and future lines of research. 
Table 1. Barriers to the development of the wind energy sector.

\begin{tabular}{|c|c|}
\hline Type of Barrier & Description \\
\hline Technological & $\begin{array}{ll}\text { - } & \text { Integration and grid connection challenges } \\
\text { - } & \text { Lack of support infrastructure } \\
\text { - } & \text { Technology maturity and performance concerns } \\
\text { - } & \text { Harsh offshore natural conditions }\end{array}$ \\
\hline Economic and market-based & $\begin{array}{l}\text { - High initial capital costs and slow return of investment } \\
\text { - } \quad \text { Limited sources of funding } \\
\text { - } \quad \text { Underdeveloped offshore supply chains } \\
\text { - } \quad \text { Ever-changing policies with impact on profits } \\
\text { - } \quad \text { Carbon emissions and local air pollutants are not priced or only partially so. }\end{array}$ \\
\hline Regulatory, political, and social & $\begin{array}{ll}\text { - } & \text { Complex/outdated regulatory frameworks } \\
\text { - } & \text { Inadequate financial policy support } \\
\text { - } & \text { Lack of relevant standards and quality control measures } \\
\text { - } & \text { Lack of qualified and experienced professional labor } \\
\text { - } & \text { Lack of long-term and stable policy goals and a well-coordinated policy mix } \\
\text { - } & \text { Transportation of wind turbine components }\end{array}$ \\
\hline Environmental & $\begin{array}{ll}\text { - } & \text { Impact on marine fauna } \\
\text { - } & \text { Visual impact } \\
\text { - } & \text { Shadow flicker } \\
\text { - } & \text { Radar interference } \\
\text { - Noise } \\
\text { - Land use } \\
\text { - Public opposition-NIMBY "Not in my backyard" }\end{array}$ \\
\hline
\end{tabular}

Source: [24] IRENA, 2019.

\section{Strategies to Beat Public Opposition}

In order to face public opposition, strategies that involve local communities in the early stages of the project and promote community ownership models have been proposed, such as: (i) working with local planning authorities and keeping them committed during the different stages of development and operation of the site [27], (ii) promoting an equitable distribution of economic benefits and costs, generating additional income from the lease of adjacent land and creating jobs for the people from the area during the installation and operation of the wind park [28], (iii) providing additional services, such as educational programs or visits, improvement and maintenance of the landscape, tourist facilities, and sponsorship of local events, among others [29], (iv) creating citizen participation mechanisms to provide local inhabitants with information and the means to air their apprehensions regarding the project and, potentially, influence its design or even its operation, such as letting local authorities stop plant operation in case of accident or malfunction.

Some authors conclude that material compensations are not fully adequate. Although they may work, their effectiveness is conditioned by their design and implementation. The problem of local opposition is resolved by establishing public policies that integrate elements of territorial, local, and national planning, with spaces for participation and consensus building, and economic compensation systems that strengthen the acceptability of projects, instead of diluting it [30].

\section{Methodology}

For the development of this research, a search was carried out for relevant literature on investment in wind energy under uncertainty in the electronic databases of Web of Science and Scopus, during the period between 2006 and 2020. The search process was carried out in two stages. In the first, two search criteria were used: (i): "wind energy investment projects with uncertainty", generating 196 publications, and (ii): "economic evaluation of 
investment in wind power generation with uncertainty, obtaining 24 publications, for a total of 220 publications.

The article selection process was made taking into account the relevance of the article content with the topic of investment in wind energy under uncertainty and the criteria of the most cited articles, with 97 articles being chosen. Subsequently, the models or approaches applied in each one were identified to evaluate wind systems.

Finally, the articles were selected under the real options approach, in which they are subjected to an exhaustive analysis to determine: (i) their purpose, (ii) uncertainties used, (iii) option valuation techniques, (iv) uncertainty modeling techniques, and (v) options used for the evaluation.

In the second stage of the search, the combination of real options and public opposition was explored, using as search criteria: Real options AND (nimby OR public opposition), obtaining only 23 studies related to the issue of public opposition to investment, but none under the real options approach to assess public opposition to investment in wind systems projects.

\section{Results Analysis}

Due to the boom in the use of wind energy, research on investment in this type of energy generation has increased over the years. A great leap is evident from 2018 onwards, when 57 articles were published, $58.8 \%$ of the selected 97 . This trend appears in Figure 1.

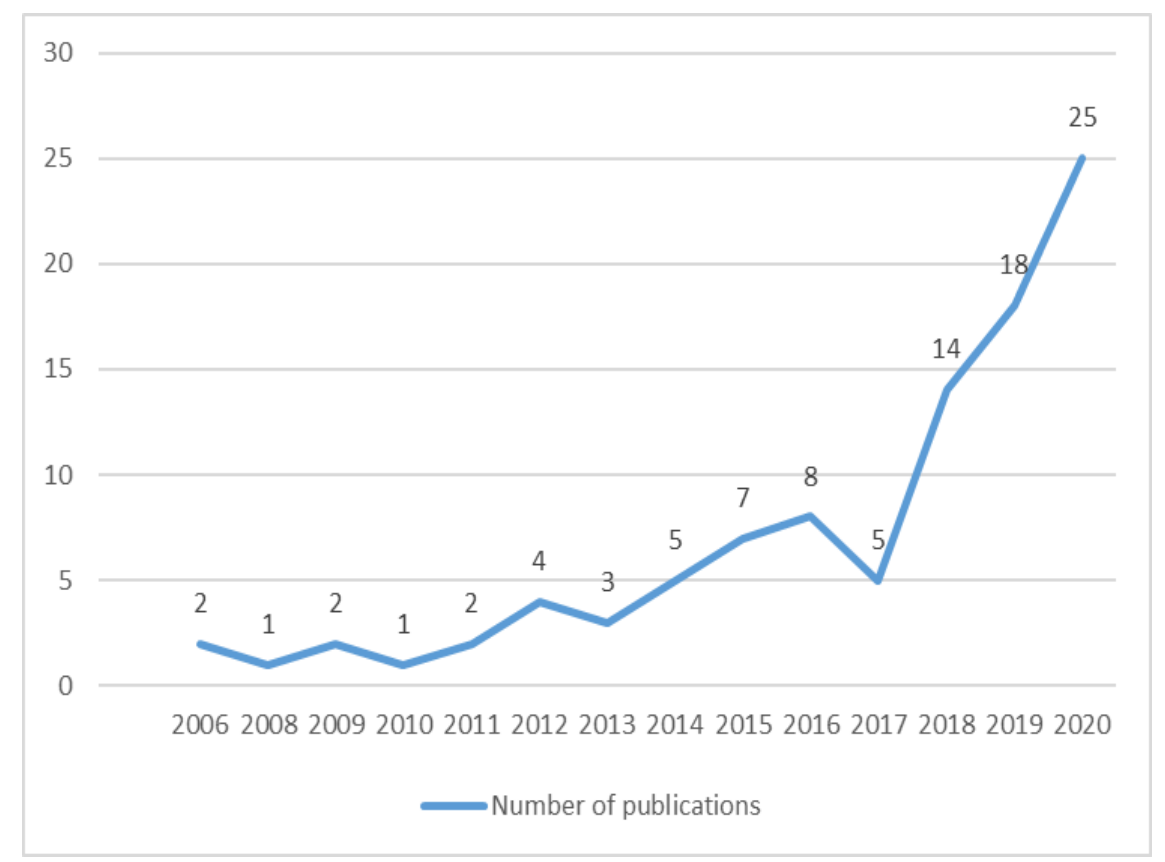

Figure 1. Research on investment in wind energy.

Throughout the literature, there are many models or approaches that was been proposed to evaluate the feasibility of investment in wind power generation, considering the impact of the uncertainty present during the study, siting, and operation phases of a wind farm. Table 2 shows the model proposed in the selected studies, considering the categorization. 
Table 2. Models or approaches used in the literature.

\begin{tabular}{|c|c|c|c|c|c|c|c|c|c|}
\hline \multirow{2}{*}{ Authors } & \multirow[t]{2}{*}{ Year } & \multicolumn{8}{|c|}{ Models or Approaches in the Literature } \\
\hline & & 1 & 2 & 3 & 4 & 5 & 6 & 7 & Others \\
\hline Kinias, Tsakalos, \& Konstantopoulos [31] & 2020 & $\checkmark$ & & & & & & & \\
\hline Detemple \& Kitapbayev [32] & 2020 & $\checkmark$ & & & & & & & \\
\hline Krömer [33] & 2020 & & & $\checkmark$ & & & & & \\
\hline Nasrolahpour, Zareipour, \& Rosehart [34] & 2020 & & & $\checkmark$ & & & & & \\
\hline Oh \& Son [35] & 2020 & & & $\checkmark$ & & & & & \\
\hline Ioannou, Angus, \& Brennan [36] & 2020 & & & $\checkmark$ & & & & & \\
\hline Mehrjerdi \& Hemmati [37] & 2020 & & & $\checkmark$ & & & & & \\
\hline Liu, He, Liang, Yang, \& Xia [38] & 2020 & & $\checkmark$ & & & & & & \\
\hline Chowdhury, Pilo, \& Pisano [39] & 2020 & & $\checkmark$ & & & & & & \\
\hline Tan et al. [40] & 2020 & & $\checkmark$ & & & & & & \\
\hline Zhan et al. [41] & 2020 & & $\checkmark$ & & & & & & \\
\hline Verleysen, Coppitters, Parente, Paepe, \& Contino [42] & 2020 & & $\checkmark$ & & & & & & \\
\hline G. Yang, Jiang, \& You [43] & 2020 & & $\checkmark$ & & & & & & \\
\hline Al, Sirjani, \& Daneshvar [44] & 2020 & & & & & $\checkmark$ & & & \\
\hline Hübler et al. [45] & 2020 & & & & & $\checkmark$ & & & \\
\hline Ge et al. [46] & 2020 & & $\checkmark$ & & & & & & \\
\hline H. Yang et al. [47] & 2020 & & $\checkmark$ & & & & & & \\
\hline Kong, Li, Liang, Xia, \& Xie [48] & 2020 & & $\checkmark$ & & & & & & \\
\hline Keck \& Sondell [49] & 2020 & & & & & & & $\checkmark$ & \\
\hline Stetter, Piel, Hamann, \& Breitner [50] & 2020 & & & & $\checkmark$ & & & & \\
\hline Abdalla, Smieee, Adma, \& Ahmed [51] & 2020 & & & & & & & & 17 \\
\hline Henckes, Frank, Küchler, Peter, \& Wagner [52] & 2020 & & & & & & & & 18 \\
\hline Niromandfam, Movahedi, \& Zarezadeh [53] & 2020 & & & & & & & & 19 \\
\hline Zhou, Wu, Dong, Tao, \& Xu [54] & 2020 & & & & & & & & 20 \\
\hline Zhao, Yao, Sun, \& Pan [55] & 2019 & $\checkmark$ & & & & & & & \\
\hline Maeda \& Watts [56] & 2019 & $\checkmark$ & & & & & & & \\
\hline Vavatsikos, Arvanitidou, \& Petsas [57] & 2019 & $\checkmark$ & & & & & & & \\
\hline Askari, Zainal, Ab, Tahmasebi, \& Bolandifar [58] & 2019 & $\checkmark$ & & & & & & & \\
\hline M. A. Abdulgalil, Khalid, \& Alismail [59] & 2019 & & & $\checkmark$ & & & & & \\
\hline Junior et al. [60] & 2019 & & & $\checkmark$ & & & & & \\
\hline M. Abdulgalil, Khalid, \& Alismail [61] & 2019 & & & $\checkmark$ & & & & & \\
\hline Yunhao Li, Wang, Gu, Liu, \& LI [62] & 2019 & & & $\checkmark$ & & & & & \\
\hline Pizarro-alonso, Ravn, \& Münster [63] & 2019 & & $\checkmark$ & & & & & & \\
\hline Yan, Zhang, Liu, Han, \& Li [64] & 2019 & & & & & $\checkmark$ & & & \\
\hline Tagliapietra, Zachmann, \& Fredriksson [65] & 2019 & & & & & & $\checkmark$ & & \\
\hline Thang \& Trung [66] & 2019 & & $\checkmark$ & & & & & & \\
\hline Quan \& Kim [67] & 2019 & & $\checkmark$ & & & & & & \\
\hline Borràs, Spelling, Weijde, \& Pavageau [68] & 2019 & & & & $\checkmark$ & & & & \\
\hline Fuchs, Marquardt, Kasten, \& Skau [69] & 2019 & & & & & & & & 9 \\
\hline Zhang et al. [70] & 2019 & & & & & & & & 8 \\
\hline Ioannou, Angus, \& Brennan [71] & 2019 & & & & & & & & 16 \\
\hline Ribeiro, Finotti, Perobelli, \& Baumgratz [72] & 2018 & $\checkmark$ & & & & & & & \\
\hline Finjord, Hagspiel, Lavrutich, \& Tangen [73] & 2018 & $\checkmark$ & & & & & & & \\
\hline Dalby, Gillerhaugen, Hagspiel, Leth-olsen, \& Thijssen [74] & 2018 & $\checkmark$ & & & & & & & \\
\hline Yanbin Li, Wu, \& Li [75] & 2018 & $\checkmark$ & & & & & & & \\
\hline Gazheli \& Bergh [76] & 2018 & $\checkmark$ & & & & & & & \\
\hline Romanuke [77] & 2018 & $\checkmark$ & & & & & & & \\
\hline Y. Yu, Wen, Zhao, Xu, \& Li [78] & 2018 & & $\checkmark$ & & & & & & \\
\hline Aaboud et al. [79] & 2018 & & $\checkmark$ & & & & & & \\
\hline Valinejad et al. [80] & 2018 & & $\checkmark$ & & & & & & \\
\hline Jiang et al. [81] & 2018 & & $\checkmark$ & & & & & & \\
\hline Deshmukh, Mileva, \& Wu [82] & 2018 & & $\checkmark$ & & & & & & \\
\hline Z. Li et al. [83] & 2018 & & $\checkmark$ & & & & & & \\
\hline Ioannou, Angus, \& Brennan [84] & 2018 & & & & $\checkmark$ & & & & \\
\hline Esmaieli \& Ahmadian [85] & 2018 & & & & & & & & 15 \\
\hline
\end{tabular}


Table 2. Cont

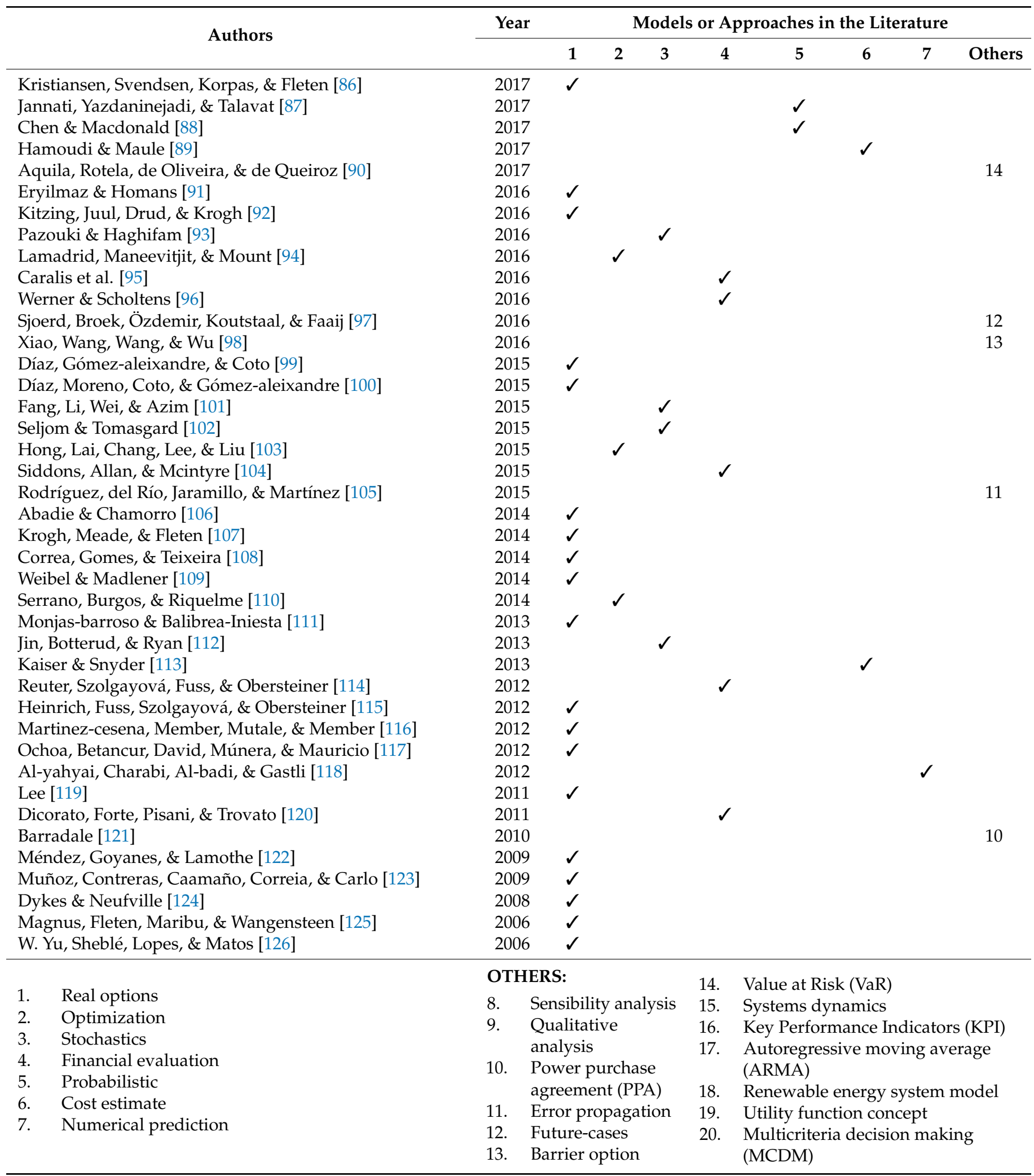

Source: the authors.

Twenty different models or approaches were identified, which were grouped into 8 categories: 1. Real options, 2. Optimization, 3. Stochastics, 4. Financial evaluation, 5. Probabilistic, 6. Cost estimate, 7. Numerical prediction, and 8. Others. Figure 2 presents the established classification and the number of articles that used it. 


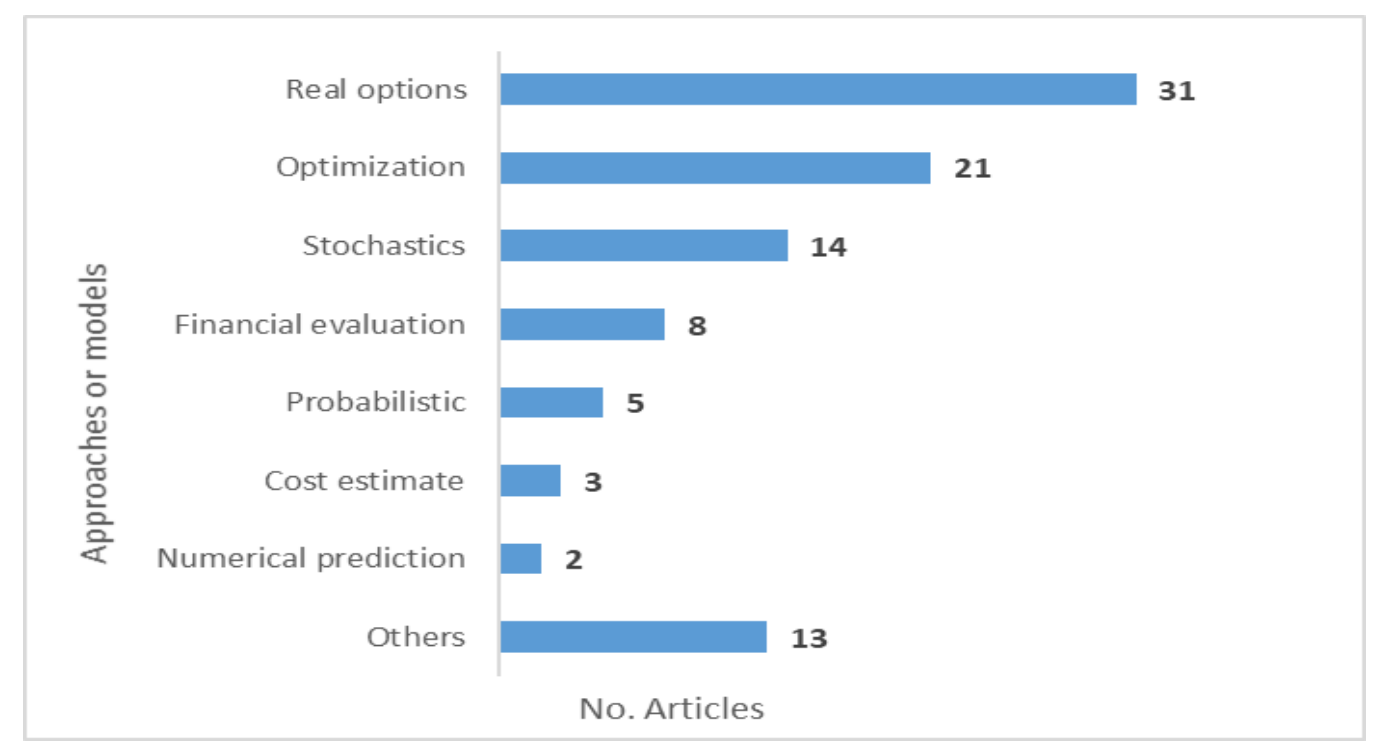

Figure 2. Categories of approaches or models used in the evaluation of investment in wind energy under uncertainty.

Among the established categories, the highest number of publications applied the real options model or approach, with $31(32 \%)$, followed by: optimization, $21(21.6 \%)$; stochastics, $14(14.4 \%)$; financial evaluation, $8(8.2 \%)$; probabilistic, $5(5.2 \%)$; cost estimate, 3 (3.1\%); numerical prediction, 2 (2.1\%); and others, 13 (13.4\%). Below is a description of each category. The category of real options will be discussed later in detail as it is the central purpose of this research.

The optimization category includes research that, with non-random variables, aims to improve efficiency with a lesser amount of resources. They include studies of robust optimizations of capacity distribution of energy systems, robust optimization of wind farm designs, and models that optimize the general design of network expansion planning and programming.

Stochastics covers research that searches for optimization by modeling the parameters of the problem through random variables. There are approaches to evaluate risks of investment in wind farms, to optimize energy generation and wind farms, or to find the optimal design and size of energy storage systems.

The financial evaluation category includes models aimed at the financial and cost evaluation of investment in energy storage systems, investment in wind farms, to evaluate the accuracy of energy cost forecasts, and financial models to establish optimal investment auctions.

Probabilistic includes the models that apply statistical techniques on data obtained through samplings to behaviors that are supposed to be random. It contemplates approaches to determine the optimal allocation of energy storage systems, to probabilistic analysis of wind farm investment designs, to model decisions of the owners and to optimize wind energy conversion processes.

The cost estimation category includes studies that focus on the projection or prediction of costs, considering two phases: determining the cost and the possible real time of the project.

The numerical prediction category includes studies that try to find a description that is as accurate as possible, within a mathematical scheme, of the true meteorological fields which behavior is to be predicted or simulated, being of great interest at the moment of proposing experiments with the models for their validation.

Others, includes approaches with an application, such as Sensitivity Analysis, Qualitative Analysis, Power Purchase Agreements (PPA), Error Propagation, Future Cases, Barrier Option, Value at Risk (VaR), System Dynamics, Parametric Performance Indicators 
(KPI), Autoregressive Moving Average (ARMA), Renewable Energy System Model, Utility Function Concept, and Multi-criteria Decision Making (MCDM).

\subsection{Studies with a Real Options Approach, Based on the Ends and Purposes of Its Application}

This article focuses on conducting a comprehensive analysis on the application of the real options approach to assess the feasibility of investments in wind energy generation projects. One of the main advantages is that it includes, by evaluating flexibility, the adjustments that the decision-maker must make when faced with uncertainty $[127,128]$.

Flexibility creates the possibility of having a range of alternatives, such as: (i) The option to postpone or defer an investment when future prospects are uncertain. It gives the holder the possibility to invest now, or to wait and acquire more information in order to assess the future conditions of the market. In the case of wind energy, it would mean postponing the construction and operation of a wind turbine until demand and prices for the technology are favorable. (ii) The option to modify the operating scale, or expanding the contract, shutting down and restarting, depending on whether market conditions turn favorable or unfavorable. A wind power plant can be expanded, downsized, even closed, depending on market conditions. (iii) The option to quit when the company observes that market conditions are becoming unfavorable. Wind energy projects are subject to changes in regulations, market conditions, and technology. (iv) The option to change, which gives the flexibility to enter and exit depending on market conditions being more favorable, important for the survival of the company. Companies have the option of deciding whether to use the land for agricultural production or to use it for wind power generation. (v) The option to grow, consisting of acquiring or developing a capacity, in anticipation, that will serve to better take advantage of future growth opportunities [58,76]. (vi) The compound option, when, at the end of an investment stage, it is possible to decide whether to stop or defer the start of the next stage. That is, the underlying asset becomes the next option [129].

Of the 97 studies included in Table 2, 31 use real options to evaluate investment in wind systems. Initially, an analysis was made based on the purposes of its application, finding various trends which were grouped into seven categories:

(1) Evaluation of wind energy generation project or investment, (2) Evaluation of energy auctions, portfolios, and energy market investments, (3) Evaluation of renewable energy technologies, (4) Evaluation of the impact of regulatory policies on wind energy projects, (5) Evaluation of wind energy systems, (6) Evaluation of wind resources, and (7) Evaluation of design, size, and location of wind farm projects, shown in Table 3.

Table 3. Investigations according to the purpose of the application in the framework of the real options approach.

\begin{tabular}{ll}
\hline \multicolumn{1}{c}{ Purpose } & \multicolumn{1}{c}{ Authors (Years) } \\
\hline Evaluation of wind energy generation project or investment & {$[31,56,72,75,77,99,100,106,117,119,123-125]$.} \\
Evaluation of energy auctions, portfolios, and energy market investments & {$[31,57,58,86,106,108,122,126]$.} \\
Evaluation of renewable energy technologies & {$[32,58,76]$.} \\
Evaluation of the impact of regulatory policies on wind energy projects & {$[32,55,73,74,91,92,107,111,126]$.} \\
Evaluation of wind energy systems & {$[86,109,114]$.} \\
Evaluation of wind resources & {$[116]$.} \\
Evaluation of design, size, and location of wind farm projects & {$[109,116]$.} \\
\hline
\end{tabular}

Source: the authors.

In Figure 3, the purposes of the studies evaluated using the options approach are observed. 


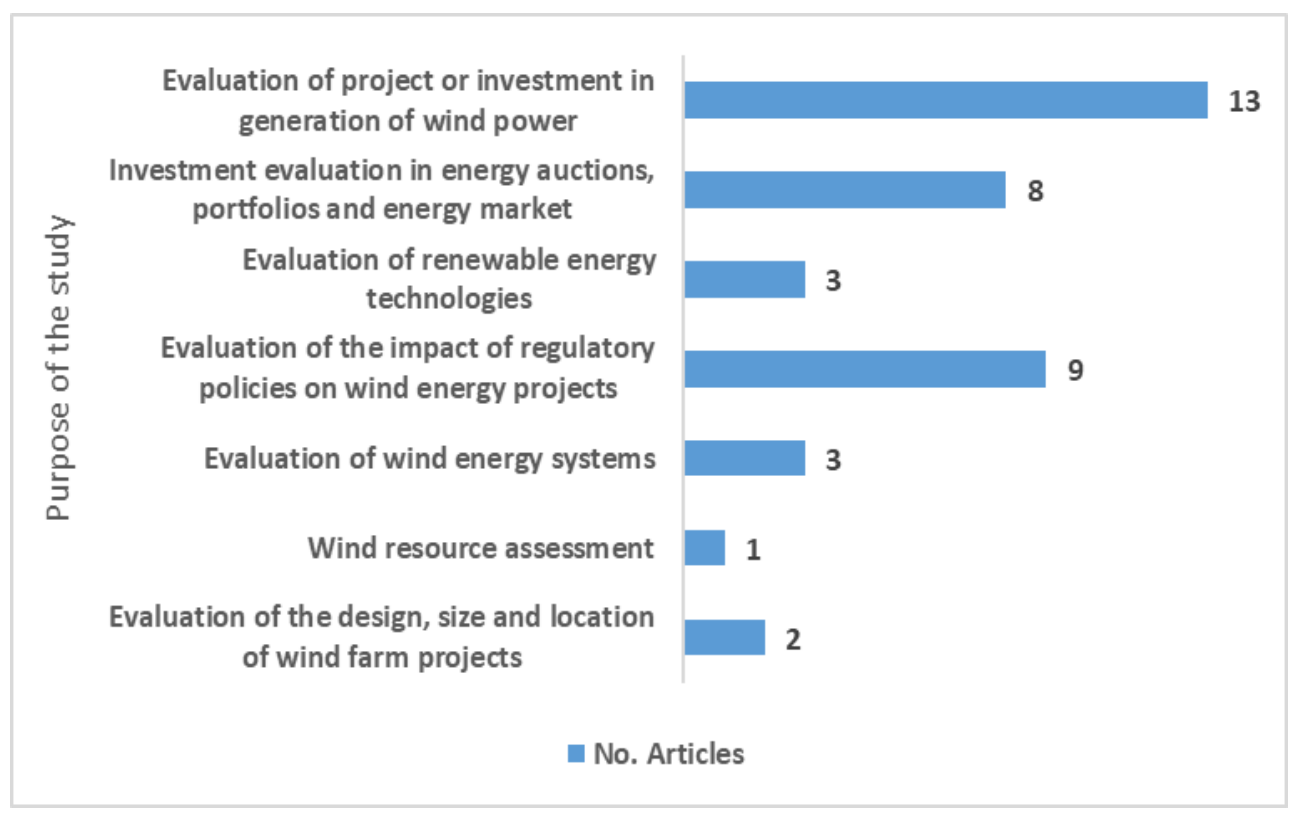

Figure 3. Purpose of the study.

The evaluation of wind energy generation project or investment includes research aimed at optimally evaluating investments from the perspective of the decentralized generation of energy or the viability of projects for the construction of wind farms, is the one of greatest interest by researchers, with the participation of 13 studies.

The evaluation of energy auctions, portfolios, and energy market investments is focused on proposing schemes to measure immersed risks in private markets and in restructuring, to evaluate investment decisions through energy auctions, or to establish portfolios with possible areas for the development of wind farm projects. Eight studies appear.

The evaluation of renewable energy technologies groups the studies focused on optimally supporting the decision to invest in a renewable energy technology, or the adoption of hybrid systems that combine several technologies, such as wind and solar photovoltaic energies, wind and thermal energies, or gas and wind plants. Three studies appear.

The evaluation of the impact of regulatory policies on wind energy projects, seeks to assess the uncertainty caused by the expectation of retroactive changes in wind energy policy, and the flexibilities associated with changing tariffs or subsidies, regulatory frameworks, support schemes such as feed rates and renewable energy certificate trading, and future renewable energy policy. There are nine publications.

The evaluation of wind energy systems, considers the investment required to adopt energy systems integrated by wind energy and hydraulic storage by pumping, or photovoltaic systems, and to expand the network by investing in stages, generating flexibility for the planning of the electrical system. There are three publications.

The evaluation of wind resources integrates studies of wind energy projects planning, considering real options for the evaluation of said resources. There is one publication.

Finally, there are studies aimed at evaluating the design, size, and location of wind farm projects to allow for optimal investment. There are two publications.

\subsubsection{Analysis by Group According to Their Application Purposes \\ Evaluation of Wind Energy Generation Project or Investment}

Uncertainties

For the evaluation of wind energy generation projects or investment, uncertainties such as electricity load, energy sales, or energy production $[77,99,123,125]$; climatic variables or wind conditions $[75,99,106,117,125]$, the price of electricity $[31,72,99,117,123-125]$, carbon price, or other incentives $[75,106,124]$, have been considered. Others have explored 
things such as market conditions, investment planning, investment costs, capital, or other costs [77,99,119], government policies, and technology levels [75], as uncertainties.

Techniques to Model Uncertainties

To model uncertainties, stochastic processes of the geometric Brownian Movement type-GBM [56,75,106,119,125], the binomial model of Cox, Ross, and Rubinstein [124], reversal of the mean $[31,72,123]$, normal distribution [31], Weibull distribution [77,123], and Box-Jenkins and Ornstein-Uhlenbeck $[99,100]$, have been used.

Used Options

The options that have been used during the evaluation are the option of expansion or closure of facilities [117,124], invest now, postpone, or abandon [72,75,99,123], or the option to switch between alternatives, either capacity [125], or investment [72].

Techniques to Evaluate Used Options

Techniques such as Black-Scholes [119,125], decision trees [106,117,123,124], the binomial model of Cox, Ross, and Rubinstein [124], Monte Carlo simulations [56,75,106,117,123,124], the Wiener process [31], Dynamic programming [56], Monte Carlo (least squares) [99,100], and optimization algorithm [77].

\section{Evaluation of Energy Auctions, Portfolios, and Energy Market Investments \\ Uncertainties}

For the evaluation of energy auctions, portfolios, and energy market investments, one can find energy production [122], electricity price [58,108,122], capital or investment costs [108,122], future deployment of offshore wind energy [86], and electricity demand [58] being considered as uncertainties.

Techniques to Model Uncertainties

To model uncertainties, stochastic processes of the Markov process type [58], Geometric Brownian movement-BGM [57,108,122], the binomial model of Cox, Ross, and Rubinstein [122], and reversal of the mean [86] were used.

\section{Used Options}

The options that have been used during the evaluation are the compound type, construction time, either to carry out, postpone, or abandon the investment [86,122], the option of waiting for a better opportunity in market trends to decide when to invest or abandon [108], and the option of building portfolios with possible areas for the development of wind farm projects [57].

Techniques to Evaluate Used Options

For evaluate the options, techniques such as dynamic programming [57,58], the optiongames model [58,108], Monte Carlo simulations [57,58,122], decision trees [122], the binomial model of Cox, Ross, and Rubinstein [122], and optimization algorithm [86] have been used.

\section{Evaluation of Renewable Energy Technologies}

Uncertainties

For the evaluation of renewable energy technologies, electricity prices were considered as uncertainty [58,76], as were: learning speed [76], electricity demand [58], government policies [32], feed-in rates-subsidies [32,115], alternative technologies [32], and the intermittency of the wind [115].

Techniques to Model Uncertainties

Stochastic processes of the Markov chains type [58], Geometric Brownian MotionGBM [32,76], and complex formulations [115] were used.

Used Options

The options that have been used are: the option to invest now or wait for when conditions are more favorable [76], to take advantage of the learning effect to anticipate the option to invest and exercise it earlier [76], the option to invest in one or more technologies, whether wind or thermal [58,76], or wind or gas [32].

Techniques to Evaluate Used Options 
Techniques such as dynamic programming [58,115], option-games model [58], Monte Carlo simulation $[32,58,115]$, and technological learning curves [76] were used.

Evaluation of the Impact of Regulatory Policies on Wind Energy Projects

Uncertainties

For the evaluation of the impact of regulatory policies in wind energy projects, electricity price $[55,73,92,111,126]$, changes in asset rates [126], energy production [73,111], investments or capital costs [107,111], price index [111], production certificates or feed-in rates-subsidies [32,73,74,107], credit policy [91], wind speed [92], wind turbines hours of use [55], carbon price [55], government policies [32], and alternative technologies [32] were considered as uncertainties.

Techniques to Model Uncertainties

To model uncertainties, stochastic processes of the reversion of the mean type [111,126], Geometric Brownian Movement-GBM [32,55,73,74,92,107], and the Markov process [74,91], have been used.

Used Options

The options used during the evaluation they were the options to invest now, postpone or abandon and the option of capacity generated by support schemes $[73,74,92,107]$, the compound option, associated with changes in wind turbines rates [126], options underlying the change in monthly or annual rate, modeled as an Asian call option on the wind differential [126] the option to invest now, postpone, or abandon [111], to adjust capacity $[55,91,111]$, as generated by regulatory frameworks; and the option to choose between technologies due to policy changes [32].

Techniques to Evaluate Used Options

To evaluate the options, techniques such as decision trees [111], Monte Carlo simulations [32,74,111,126], Black-Scholes [92,107], Monte Carlo (least squares) [55,73,107], dynamic programming [74,91,92], and technological learning curves [74] have been used.

Evaluation of Wind Energy Systems

Uncertainties

For the evaluation of wind energy systems, feed rate-subsidies [115], intermittency of the wind [115], future deployment of wind energy process [86], and wind speed [116] were used as uncertainties.

Techniques to Model Uncertainties

To model uncertainties, tools such as complex formulations [115], stochastic processes of the reversion of the mean type [86], and symmetric distributions [86], were used.

Used Options

The options used for the evaluation are of the construction time type; that is, the option to make the investment for the expansion of the network in stages, where the second stage generates flexibility when planning the electrical system $[86,115]$, and the option to delay the construction of wind energy projects [116].

Techniques to Evaluate Used Options

Techniques such as dynamic programming [115], Monte Carlo simulations [115,116], algorithm optimization [86] and decision trees [116] have been used for the valuation of options.

Evaluation of Wind Resources

Uncertainties

For the evaluation of wind resources, the speed of wind was considered an uncertainty [116].

Techniques to Model Uncertainties

The modeling of uncertainties was carried out using the Weibull distribution and decisions trees [116].

Used Options 
The option used was that to delay the construction of wind energy projects to gather more relevant data to evaluate wind resources [116].

Techniques to Evaluate Used Options

The evaluation of options was carried out using Monte Carlo simulations and decisions trees [116].

Evaluation of Design, Size, and Location of Wind Farm Projects

Uncertainties

For the evaluation of the design, size and location of wind farm projects, the uncertainties were solar irradiation, electricity price, capital costs, wind intensity [109], and wind speed [116].

Techniques to Model Uncertainties

To model uncertainties, stochastic processes of the Geometric Brownian Movement type-GBM [109], the Weibull distribution, and decision trees [116] were used.

Used Options

The option used was that to delay the construction of wind energy projects [116].

Techniques to Evaluate Used Options

The evaluation of options has been carried out using Monte Carlo simulations [109,116] and decision trees [116].

\subsection{Types of Uncertainties Explored in Publications with a Real Options Approach}

Uncertainty is inherent in events where possible outcomes are not known, and, therefore, their probability of occurrence cannot be quantifiable. Regarding projects, uncertainty grows over time, conditioning the occurrence of viability. The management of uncertainty, over the years, has always been a critical variable for decision-makers [130]. In the energy sector, including wind energy, decision-making is generally always conditioned by a level of uncertainty in the data [131].

In the selected articles, with a real options approach, 28 types of uncertainties were identified, which were grouped into nine categories: 1. Power generation, 2. Environmental conditions, 3. Energy price, 4 . Costs, 5 . Revenues, 6 . Regulatory policies, 7. Market, 8. Wind conditions, and 9. Technological progress, as shown in Table 4.

Table 4. Types of uncertainties explored in research with a real options approach.
1. Power Generation
1.1. Electricity charge
1.2. Wind energy level
1.3. Energy production
1.4. Wind turbine hours of use
1.5. Investment planning
1.6. Future deployment of wind energy

\section{Environmental}

2.1. Climate change

2.2. Solar irradiation

\section{Prices}

3.1. Electricity price

3.2. Carbon price

3.3. Corn price

\section{Costs}

4.1. Capital costs

4.2. Investment costs
5. Regulatory Policies
5.1. Production certificates
5.2. Changes in asset rates
5.3. Credits policy
5.4. Government policies
5.5. Feed-in rates-subsidies

\section{Market}

6.1. Market conditions

6.2. Price index

6.3. Demand for electricity

\section{Wind Conditions}

7.1. Wind disponibility

7.2. Wind intensity

7.3. Wind speed

7.4. Wind intermittency

8. Technological Progress

8.1. Alternative technology

8.2. Technology levels

8.3. Learning speed 
1. Power generation contains the uncertainties that affect the process of generating wind energy, such as electricity charge, wind energy level, energy production, wind turbine hours of use, investment planning, and future deployment of wind energy. Energy production prevails, with three applications, as shown in Figure 4.

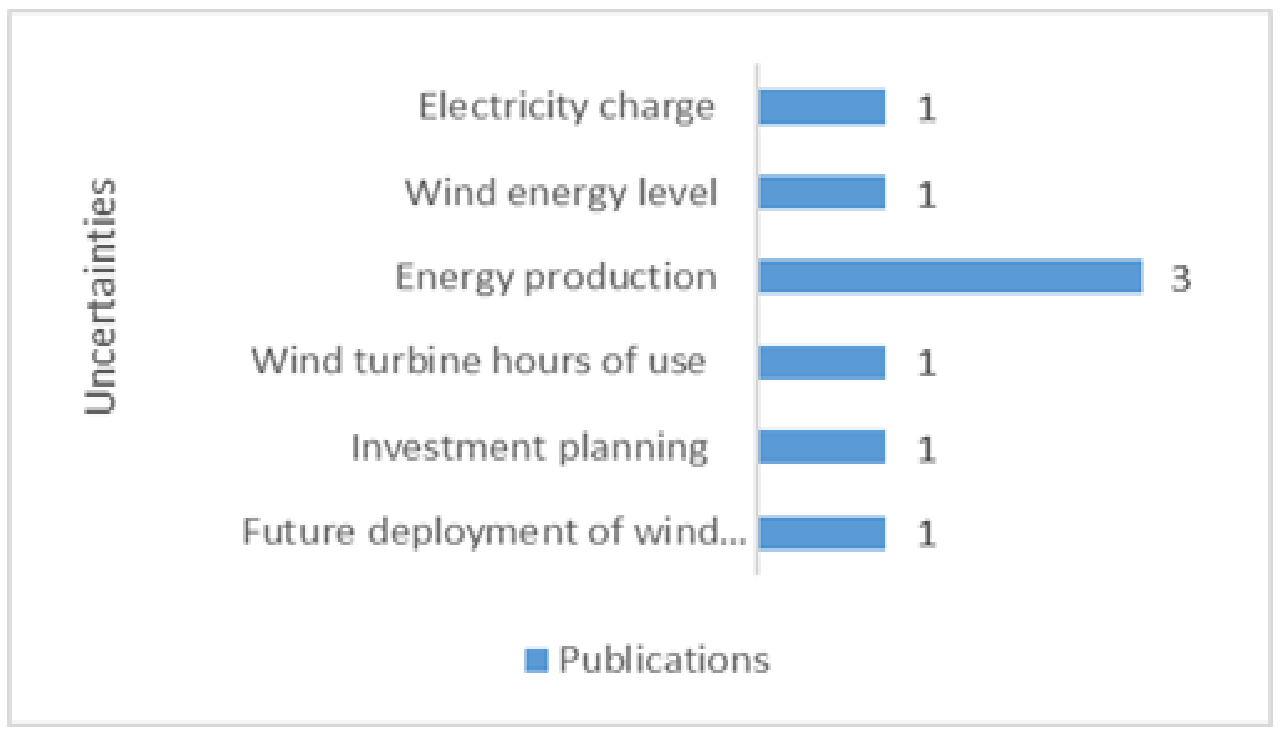

Figure 4. Power generation.

2. Environment refers to the uncertainties present in environmental conditions necessary for the development of projects such as climate change and solar irradiation. Solar irradiation stands out, with two applications, as shown in Figure 5.

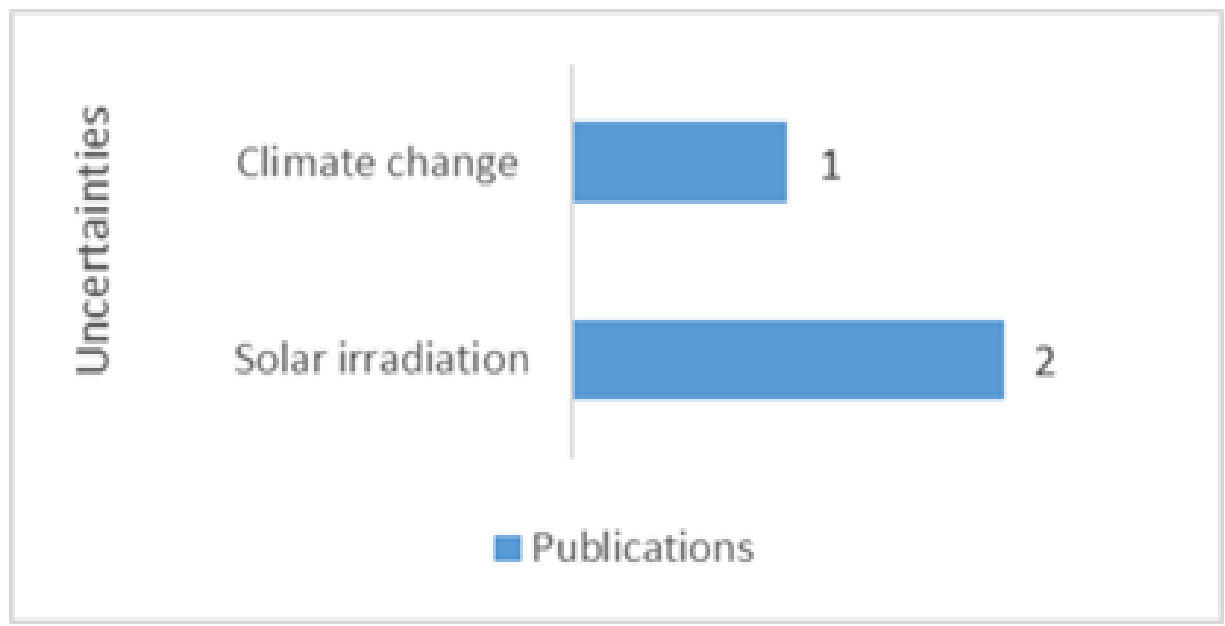

Figure 5. Environment.

3. Energy price considers the uncertainties generated by price fluctuations in the market, in response to the behavior of energy demand and supply, including among others the price of electricity, coal price, and the price of corn. The price of electricity is the source of uncertainty most studied by researchers, being considered in $20(65.5 \%)$ publications, as shown in Figure 6. 


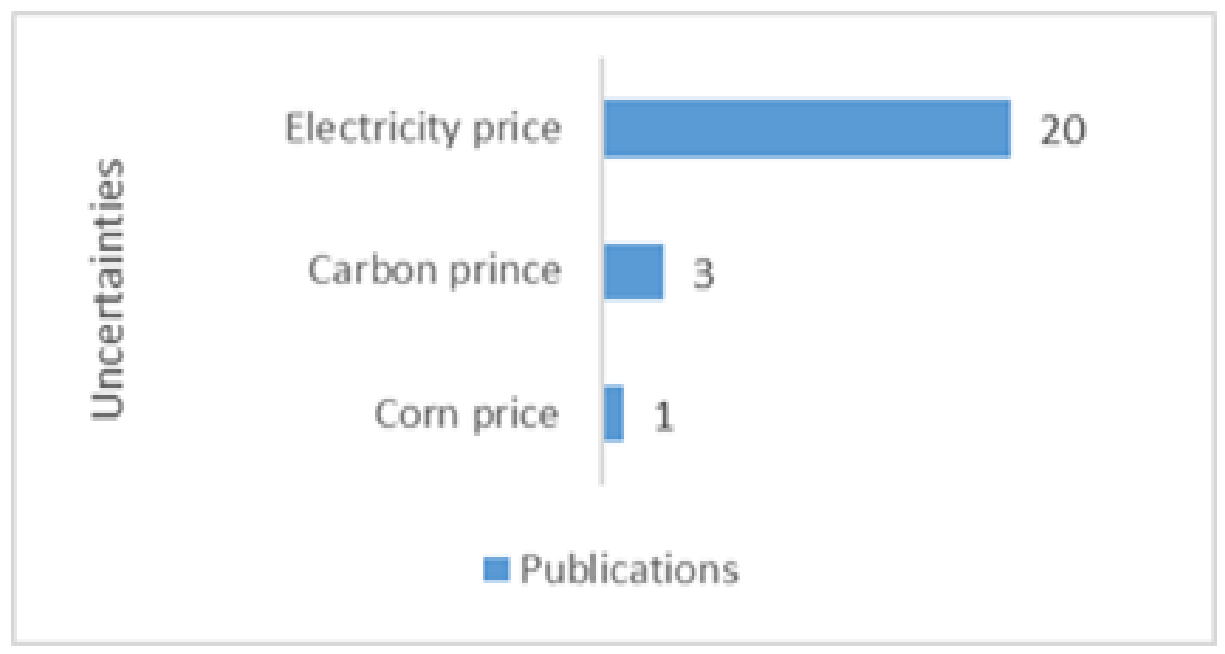

Figure 6. Energy price.

4. Costs studies were integrated that analyze the uncertainties caused by the incidence of the behavior of costs in the profitability of the investment, whether they are capital costs or investment costs. Both costs were studied in four publications, as shown in Figure 7.

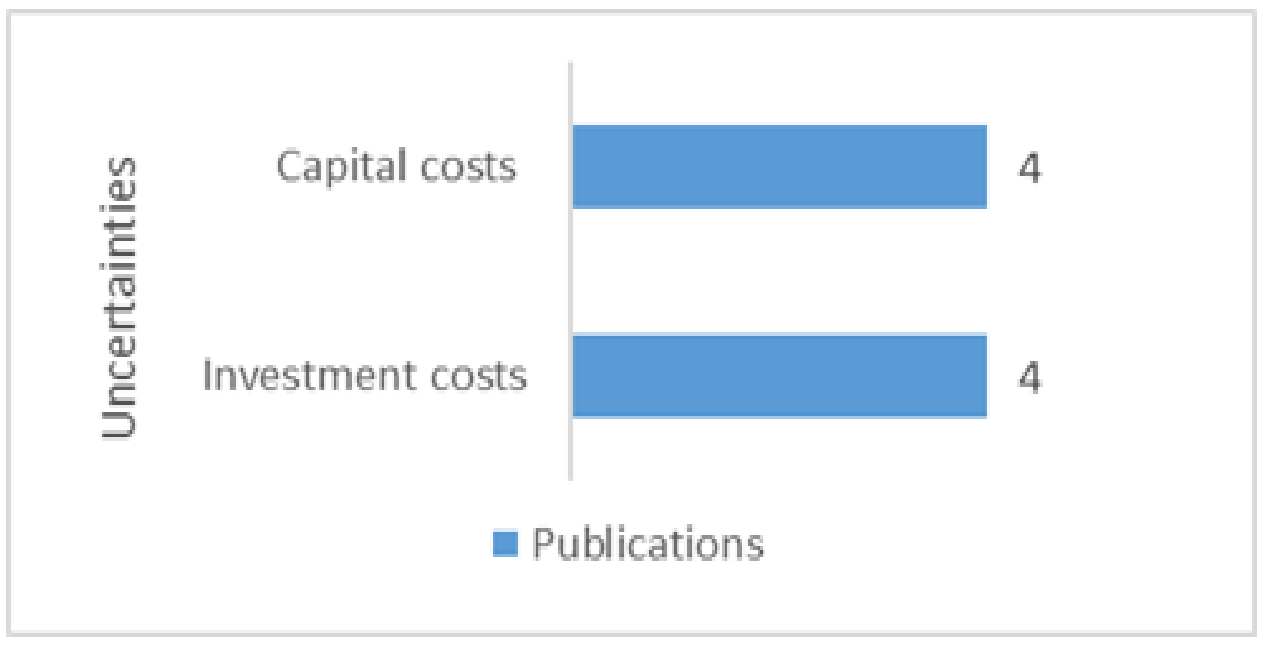

Figure 7. Costs.

5. Regulatory policies include the uncertainties caused by changes implemented in the policies for the generation of wind energy, among which are production certificates, changes in asset tariff, credit policy, government policies, and feed-in tariffs-subsidies. The rates of food and subsidies have been the most studied by researchers, being considered in five publications, as reflected in Figure 8. 


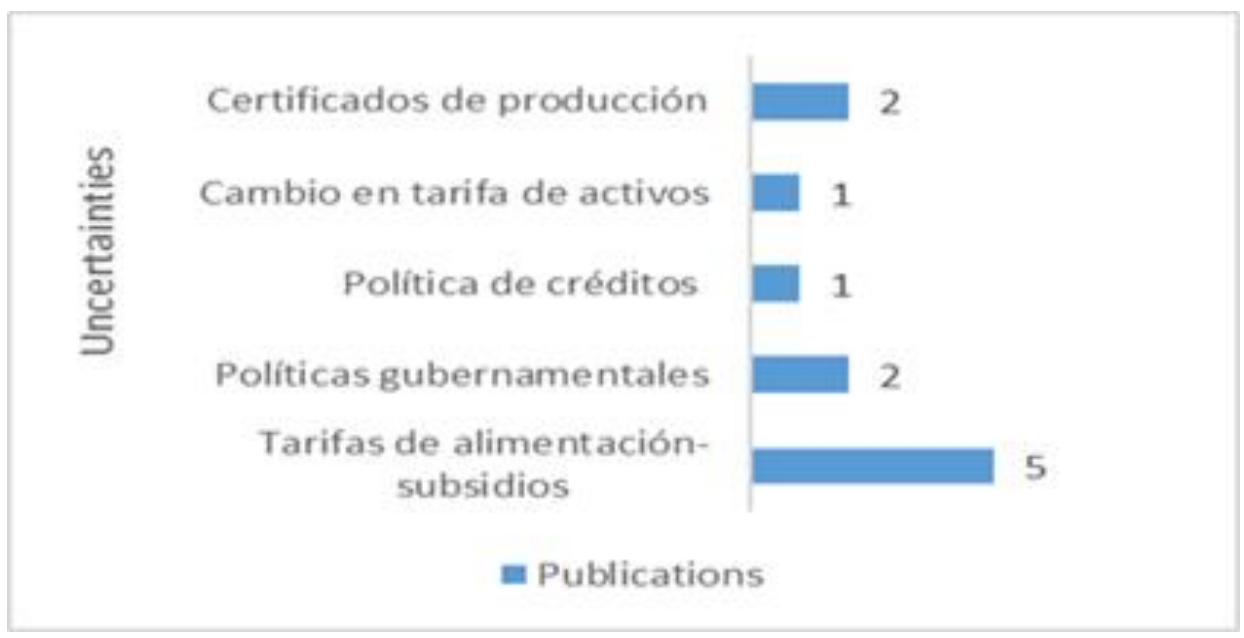

Figure 8. Regulatory policies.

6. Market relates sources of uncertainties other than prices and costs which affect their market behavior, such as market conditions, price indices, and electricity demand. Market conditions prevail, with three applications, as shown in Figure 9.

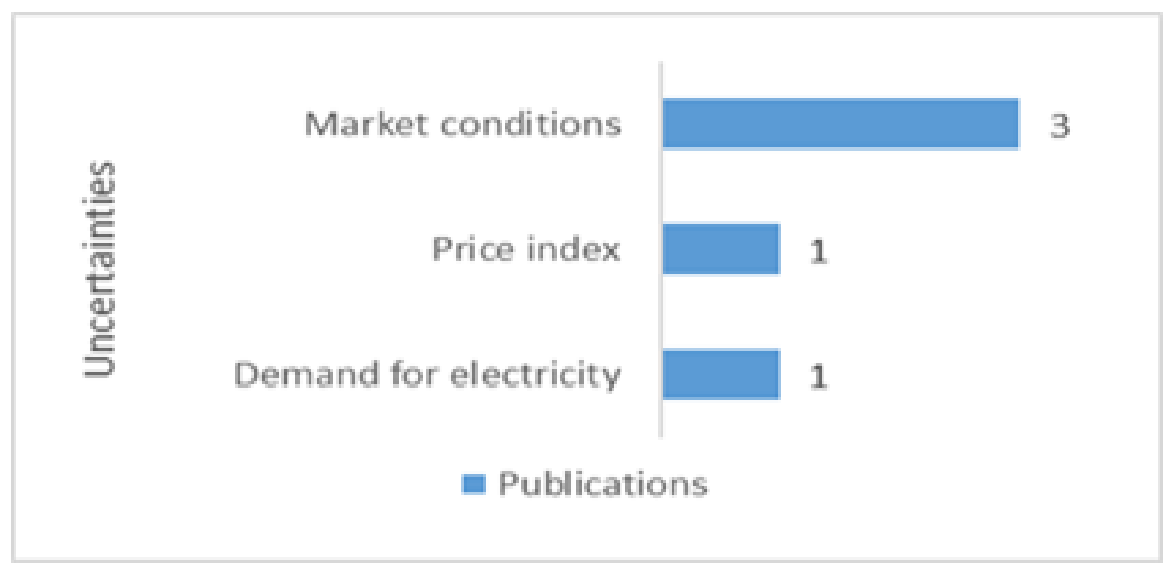

Figure 9. Market.

7. Wind conditions addresses uncertainties caused by variability of the wind characteristics in the generation of wind energy, such as the availability of wind, its intensity, its speed, and its intermittency. After the price of electricity, wind conditions are the source of uncertainty that generates the greatest interest in the studies analyzed, especially wind speed, as it has a great impact on the generation of wind energy. Wind speed was studied in six publications, as shown in Figure 10. 


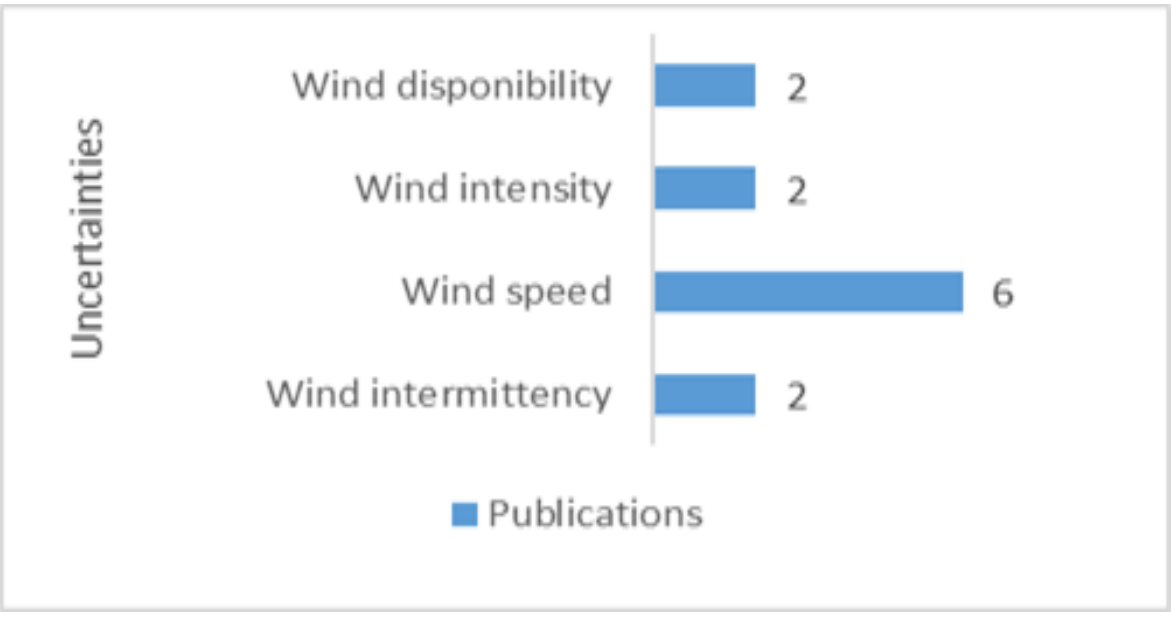

Figure 10. Wind conditions.

8. Technological progress focuses on the analysis of the uncertainties caused by the generation and use of knowledge (R\&D) that affect the productivity, such as alternative technology, technology levels, and learning speed. All sources of uncertainties have only been studied in one investigation, as shown in Figure 11.

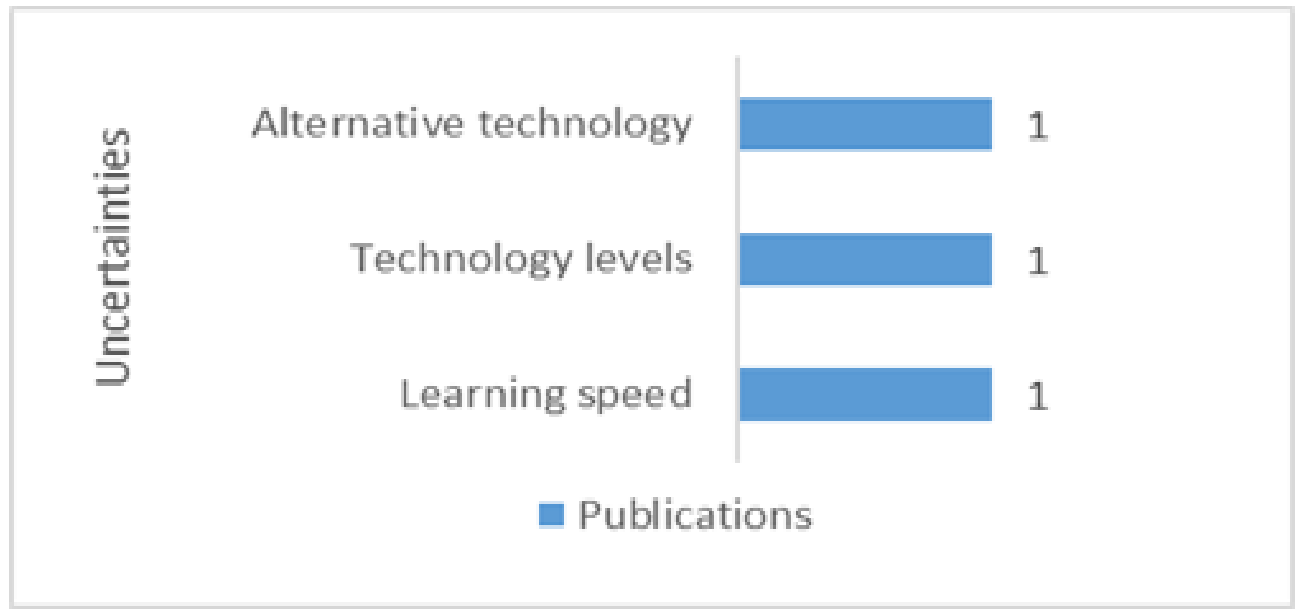

Figure 11. Technological progress.

Table 5 shows, in a disaggregated manner, the type of uncertainty considered in each of the studies with a focus on real options to evaluate investment in wind systems, taking into account the categorization of Table 4 . It is observed that $62.5 \%$ of the studies treat the price of electricity as a source of uncertainty, $18.8 \%$ wind speed, and $15.6 \%$ feeding-subsidy rates. 
Table 5. Type of uncertainties explored in research with a real options approach.

\begin{tabular}{|c|c|c|c|c|c|c|c|c|c|c|c|c|c|c|c|c|c|c|c|c|c|c|c|c|c|c|c|c|c|}
\hline \multirow[t]{2}{*}{$\begin{array}{l}\text { Authors- } \\
\text { Years }\end{array}$} & \multicolumn{6}{|c|}{ 1. Power Generation } & \multicolumn{2}{|c|}{$\begin{array}{c}2 . \\
\text { Environ- } \\
\text { mental }\end{array}$} & \multicolumn{3}{|c|}{ 3. Prices } & \multicolumn{2}{|c|}{ 4. Costs } & \multicolumn{5}{|c|}{ 5. Regulatory Policies } & \multicolumn{3}{|c|}{ 6. Market } & \multicolumn{4}{|c|}{$\begin{array}{l}\text { 7. Wind } \\
\text { Conditions }\end{array}$} & \multicolumn{3}{|c|}{$\begin{array}{c}8 . \\
\text { Technological } \\
\text { Progress }\end{array}$} & \multirow[t]{2}{*}{ Tota } \\
\hline & 1.1 & 1.2 & 1.3 & 1.4 & 1.5 & 1.6 & 2.1 & 2.2 & 3.1 & 3.2 & 3.3 & 4.1 & 4.2 & 5.1 & 5.2 & 5.3 & 5.4 & 5.5 & 6.1 & 6.2 & 6.3 & 7.1 & 7.2 & 7.3 & 7.4 & 8.1 & 8.2 & 8.3 & \\
\hline$[125]$ & 1 & & & & & & $\checkmark$ & & 1 & & & & & & & & & & & & & & & 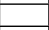 & & & & & 3 \\
\hline$[124]$ & & & & & & & & & $\sqrt{2}$ & $d$ & & & & & & & & & & & & & & & & & & & 2 \\
\hline$[122]$ & & & $\checkmark$ & & & & & & 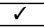 & & & $\checkmark$ & & & & & & & & & & & & & & & & & 3 \\
\hline$[106]$ & & 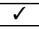 & & & & & & & $d$ & & & & & $\checkmark$ & & & & & & & & & & & & & & & 3 \\
\hline$[72]$ & & & & & & & & & 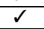 & & $d$ & & & & & & & & & & & & & & 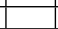 & & & & 2 \\
\hline [119] & & & & & $\checkmark$ & & & & & & & & & & & & & & $\checkmark$ & & & & & & & & & & 2 \\
\hline [31] & & & & & & & & & $\checkmark$ & & & & & & & & & & & & & & & & & & & & 1 \\
\hline$[126]$ & & & & & 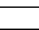 & & & & 1 & & 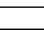 & & & & $\frac{1}{d}$ & & & & & & & $\frac{1}{2}$ & & & & & & & 3 \\
\hline [115] & & & & & & & & & & & & & & & & & & 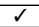 & & & & & & & $d$ & & & & 2 \\
\hline$[107]$ & & & & & & & & & 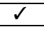 & & & 2 & & 2 & & & & $\checkmark$ & & & & & & & & & & & 4 \\
\hline$[108]$ & & & & & & & & & & & & & & & & & & & $\checkmark$ & & & & & 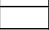 & 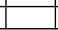 & & & & 1 \\
\hline [91] & & & & & & & & & & & & & & & & 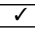 & & & & & & & & & & & & & 1 \\
\hline [73] & & & $\checkmark$ & & & & & & 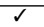 & & & & & & & & & 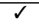 & & & & & & & & & & & 3 \\
\hline$[74]$ & & & & & & & & & & & & & & & & & & $\frac{1}{2}$ & & & & & & & & & & & 1 \\
\hline [55] & & & & 2 & & & & & $\checkmark$ & $d$ & & & & & & & & & & & & & & & & & & & 3 \\
\hline$[32]$ & & & & & & & & & & & & & & & & & 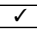 & 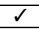 & & & & & & & & $\begin{array}{ll} \\
\end{array}$ & & & 3 \\
\hline 1111] & & & $d$ & & & & & & 1 & & & & $d$ & & & & & & & 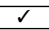 & & & & & & & & & 4 \\
\hline [92] & & & & & & & & & $\checkmark$ & & & & & & & & & & & & & & & $\checkmark$ & & & & & 2 \\
\hline$[56]$ & & & & & & & & & 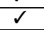 & & & & $\checkmark$ & & & & & & & & & & & & & & & & 2 \\
\hline [99] & & & & & & & & & $\checkmark$ & & & $d$ & $d$ & & & & & & & & & & & & & & & & 3 \\
\hline [123] & & & & & & & & & $d$ & & & & & & & & & & & & & & & $\checkmark$ & & & & & 2 \\
\hline$[116]$ & & & & & & & & & & & & & & & & & & & & & & & & $\checkmark$ & & & & & 1 \\
\hline [117] & & & & & & & & & 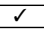 & & & & & & & & & & & & & $\frac{1}{2}$ & $\checkmark$ & 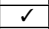 & 2 & & & & 5 \\
\hline [109] & & & & & & & & $d$ & $d$ & & & $d$ & & & & & & & & & & & $d$ & & & & & & 4 \\
\hline$[100]$ & & & & & & & & & 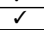 & & & & $d$ & & & & & & & & & & & $\checkmark$ & & & & & 3 \\
\hline [75] & & & & & & & $d$ & & & $\checkmark$ & & & & & & & 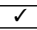 & & & & & & & & & & 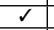 & & 4 \\
\hline [76] & & & & & & & & & $\checkmark$ & & & & & & & & & & & & & & & & & & & $\checkmark$ & 2 \\
\hline$[57]$ & & & & & & & & & & & & & & & & & & & $\checkmark$ & & & & & & & & & & 1 \\
\hline$[58]$ & & & & & & & & & 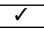 & & & & & & & & & & & & 2 & & & & & & & & 2 \\
\hline$[86]$ & & & & & & $\checkmark$ & & & & & & & & & & & & & & & & & & & & & & & 1 \\
\hline$[77]$ & & & & & & & & & & & & & & & & & & & & & & & & $\checkmark$ & & & & & 1 \\
\hline Total & 1 & 1 & 3 & 1 & 1 & 1 & 1 & 2 & 20 & 3 & 1 & 4 & 4 & 2 & 1 & 1 & 2 & 5 & 3 & 1 & 1 & 2 & 2 & 6 & 2 & 1 & 1 & 1 & 74 \\
\hline
\end{tabular}

Source: the author.

\subsection{Evaluation of Real Options and Modeling of Uncertainties}

There are multiple techniques used to assess the real options in the studies analyzed. They are random or numerical and non-random methods or by scenario analysis. Table 6 presents the classification and the studies that used each of the techniques. Within the non-randomized methods, the following techniques were identified:

(1) Decision trees: initially introduced by Cox, Ross, and Rubinstein (1979) as a binomial model to value American-type options. It was later adapted to simulate the evolution of uncertainty in discrete scenarios of multiple interrelated options [132]. It allows modeling the evolution of the price of the underlying asset under uncertainty in discrete scenarios, assuming that the underlying asset follows a multiplicative binomial process [133].

(2) Dynamic programming: an optimization method by way of dividing the problem into superimposed subproblems and optimal substructures, especially when the subproblems are not independent. It is based on the principle of optimum as enunciated by Bellman in 1957: "In an optimal decision sequence, every subsequence must also be optimal", and it allows combining different types of real options with various possible scenarios [134].

(3) Partial Differential Equations: a set of equations, initially used for the valuation of financial options $[135,136]$, later adapted to evaluate specific real options under fixed assumptions [132]. The results of the Black-Scholes model can be obtained from a binomial model for $\mathrm{n}$ periods, where $\mathrm{n}$ tends to infinity [137].

(4) Option-Games model: a valuation tool that combines the real option approach with game theory, with the aim of quantifying the values of flexibility, allowing for better investment decisions to be taken [138].

(5) Sensitivity analysis: measures the impact that variations in one of the independent variables have on the model [31].

Among the random or numerical models, we find:

(1) Monte Carlo simulation: a numerical method used to evaluate options when there are no closed formulas such as Black-Scholes [137]. Its purpose is to easily value real options for complex projects, since it does not require the formulation of cash flow through differential equations or trees [139]. It creates a distribution of project values from all given sources of uncertainty [140]. An advantage of this method is that it 
offers the distribution of the volatility factor, which is key in evaluating the sensitivity of the value of the real options of a project [141].

(2) Least squares Monte Carlo: combines the Monte Carlo simulation with least squares regression, which helps reduce the number of scenarios while still producing an accurate assessment [142]. At any time, the holder of an American option can optimally compare the reward of exercising that option immediately, with the expected reward of not exercising it yet [143].

(3) Optimization algorithms: includes traditional algorithms, such as gradient-based methods and quadratic programming, evolutionary algorithms, heuristic or metaheuristic algorithms, and various hybrid techniques. Optimization problems tend to be non-linear with complex objectives [144].

Figure 12 shows the techniques used for the valuation of Real Options. They are grouped in two blocks. In the upper one, there are the non-random techniques, with the highest prevalence of Decision Tree and Dynamic Programming with 8 (25.8\%) applications each. In the lower one, there are random techniques, among which Monte Carlo simulation is the most preferred by researchers, with $16(51.6 \%)$ applications, which is due to the fact that most of the selected studies contemplate continuous uncertainties such as, for example, the price of energy and wind conditions.

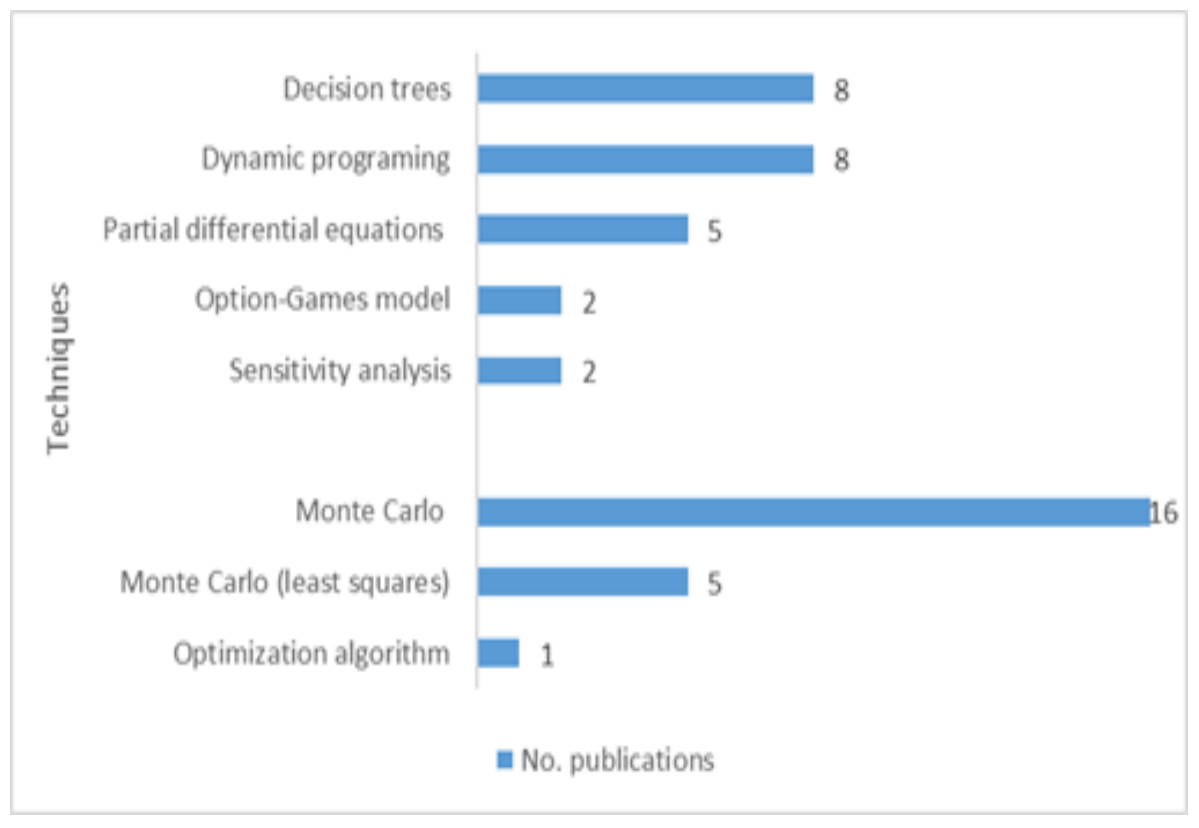

Figure 12. Real options valuation techniques.

Similarly, for the modeling of the sources of uncertainties, a great variety of techniques have been applied. Table 6 shows the different techniques applied in the selected studies. There are random techniques or models, such as:

(1) Geometric Brownian Motion, used in 61.3\% (19) of the studies, is a stochastic process in continuous time, generated from a transformation of a standard Wiener process, with the particularity of not allowing asset prices to take negative values [145]. Geometric Brownian Motion appears to be better suited to long-term energy-related investments [146].

(2) Reversal of the mean indicates that values, such as prices, may move away from the mean or intrinsic value, but, over time, they will eventually return to those mean values [147].

(3) The Weibull distribution is the probability function that best describes the wind speed path, thanks to the orthogonal composition of two correlated Gaussian functions. The Weibull density function consists of two parameters: one refers to the 
maximum speed and the other indicates the degree of dispersion of the samples (Muñoz et al., 2009).

(4) The Box-Jenkins and Ornstein-Uhlenbeck model is the basis of all modern time series analysis theory, and consists of the analysis of probabilistic or stochastic properties of economic time series where the endogenous variable $(\mathrm{Yt})$ is explained by past values or lags of itself and by stochastic error terms [148].

(5) The ARIMA distribution is an econometric methodology based on dynamic models using time series data, made up of three components: the autoregressive (AR), the integration (I), and the moving average (MA), represented by the parameters $\mathrm{p}, d$, and $\mathrm{q}$, respectively. The model includes the values of the series, prediction of errors, and a random term [149].

(6) The normal distribution is a mathematical model that allows determining probabilities of occurrence for different values of the variable. The graph of the normal distribution has the shape of a bell, and for this reason it is also known as the Gaussian bell, whose central elements are the mean and the variance [150].

(7) Markov chains are discrete stochastic processes used to study the evolution of certain systems in repeated trials, in which the probability of an event occurring depends only on the immediately preceding event. Transition probabilities are used to describe the way the system passes to the next state.

There are also non-random uncertainty modeling techniques, the binomial model of Cox, Ross, and Rubinstein, used to model non-random uncertainties in discrete time, and learning curves, used to model technological uncertainty. This concept was generated from a study by Wright (1936), where he analyzes repetitive production in the construction of airplanes, finding, as a hypothesis, that "the man-hours necessary to complete a production unit would decrease in a constant percentage each time the production doubles" [151], showing that the repetitive action of a process increases the experience and learning on the part of the operator, managing to reduce the production time per unit [152].

Figure 13 shows the techniques used to model the uncertainties studied. They are grouped in two blocks. In the upper part, there are the random techniques, and in the lower part, the non-random ones. It can be seen that the researchers opt for random techniques, preferably Geometric Brownian Motion (GBM), which is consistent with the type of uncertainty considered in the studies, which are mostly continuous, such as electricity prices and wind conditions.

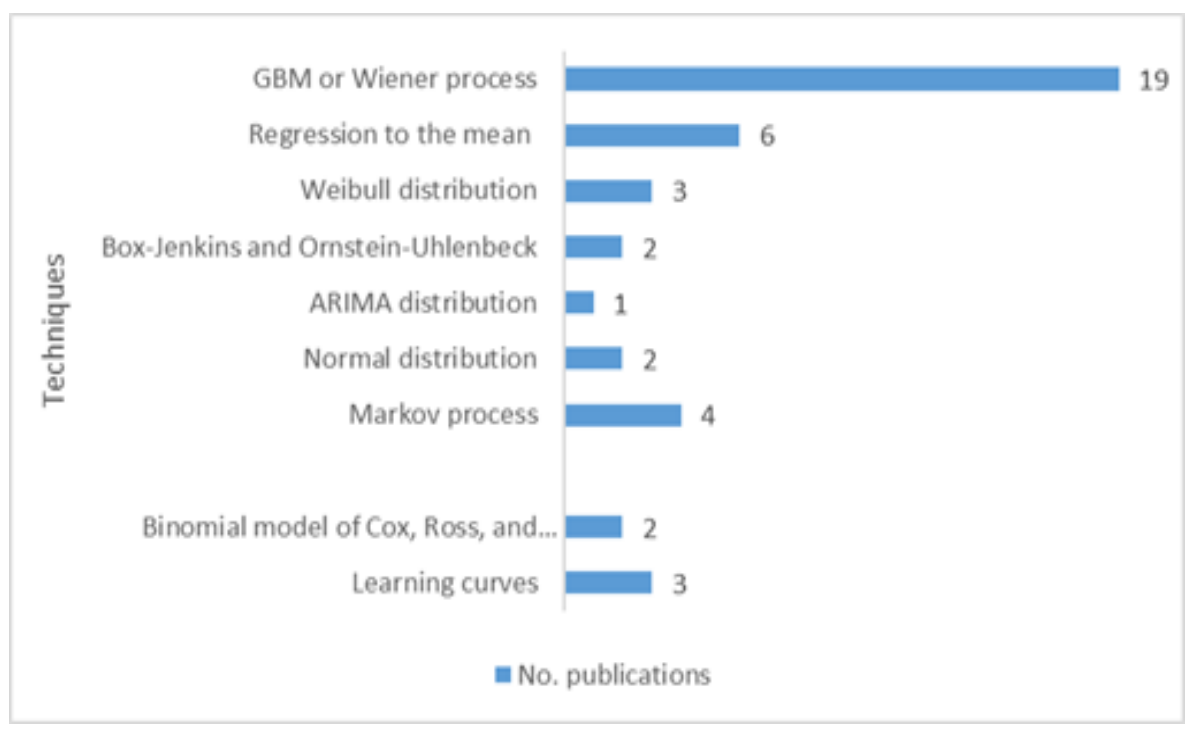

Figure 13. Uncertainty modeling techniques.

Both in evaluating real options and in modeling uncertainties, a standard pattern has not been followed when developing the models, regarding the type and number of 
techniques to be used, which indicates that, without exception, techniques are combined according to the purpose and scope of each particular study, as seen in Table 6.

Table 6. Techniques to evaluate real options and to model uncertainties.

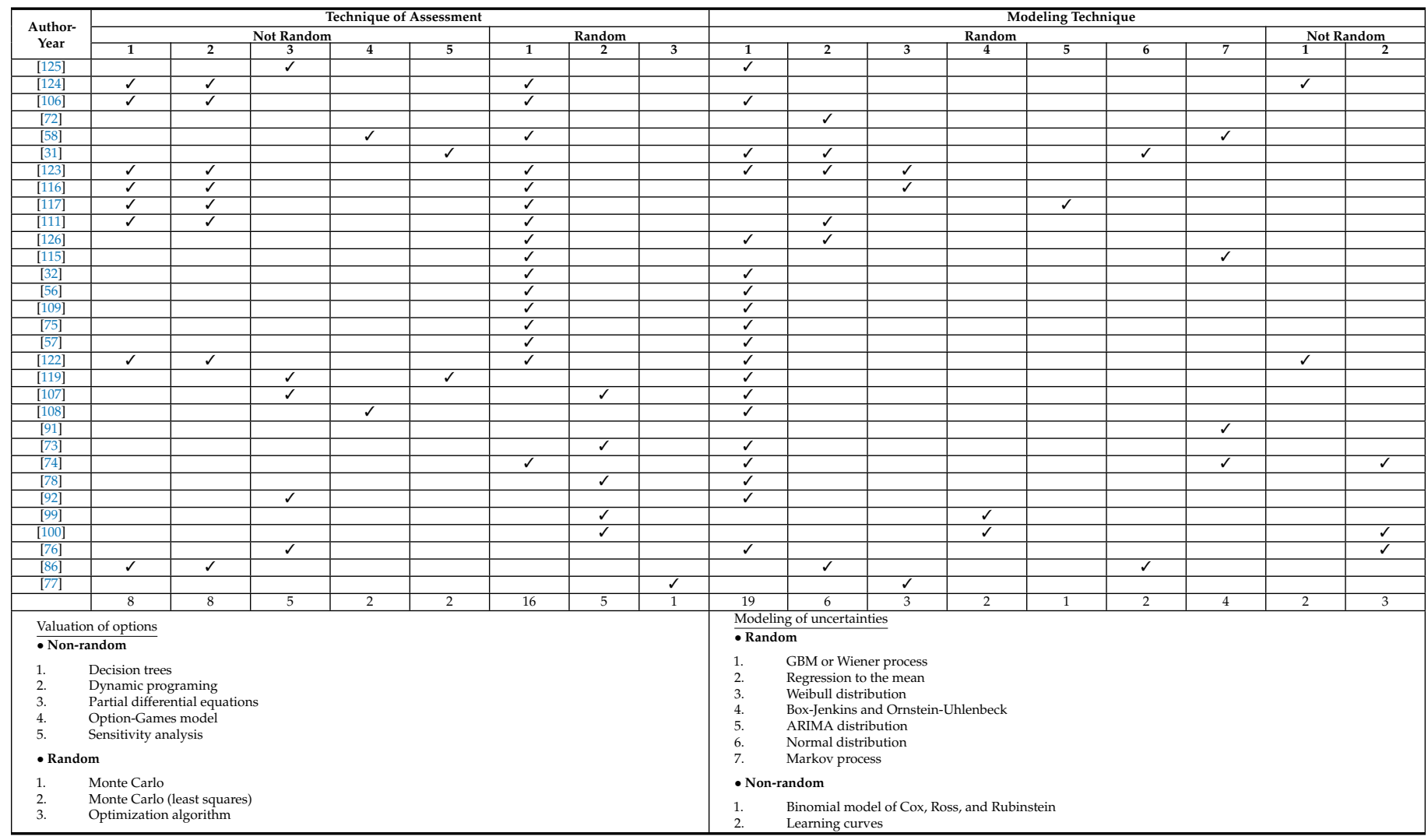

Source: the authors.

\subsection{Public Opposition under Real Options}

The literature search did not find studies that consider uncertainties related to public opposition analyzed under the real options approach; however, some studies that focus their purpose on public opposition to investment in wind energy projects [153-155], to the assembly of transmission lines [156], and to road pricing [157] were identified.

The aspects that generated the greatest public opposition in the execution of the projects were: centralized planning processes [154], implementation of a single technology [156,158], lack of communication prior to decision-making processes [154], environmental impact [155], consultation after decision-making for project execution [154], institutional factors [155], electromagnetic fields [156], network problems [156] and authorization procedures and legal framework [156].

In some studies, solutions to counteract public opposition were proposed, such as: improving the legal framework and procedures [156], implementing different technological options [156,158], participatory models for decision-making $[153,154,156]$, the implementation of financial incentive policies, including permanent tax deductions and investment support or subsidies $[157,158]$, participatory financial investment in projects [158], subsidizing the implementation of Renewable Energy Technology systems at the community level, according to customs and conditions of the housing [158], strengthening information processes and prior consultations [155,156], controling and monitoring the environmental impact [155], and building up institutional capital [153,154].

Surveys $[153,154,158]$ and panels [157] were the preferred methodologies when developing these research.

Socio-economic, situational, and family restrictions have a great impact on the decision of the participants to change their position regarding the execution of projects. 


\section{Discussion}

The purpose of this article is to review the literature on the evaluation of investment in wind systems under the real options approach, to determine the inclusion of public opposition (NIMBY projects) as a source of uncertainty, and to identify the flexible strategies implemented to overcome these types of barriers. As a result of the review, no studies related to the subject of public opposition (NIMBY projects) were found under the real options approach; however, some aspects that generate opposition were identified, which could be valued as real options, such as: the creation of participatory public policies; participatory models for decision-making; financial incentive schemes, including tax deductions and permanent investment support or subsidies; associative schemes for participatory financial investment in projects; implementation of technology systems of Renewable Energies at the community level, according to customs and housing conditions; information processes and prior consultations; environmental monitoring and control systems; and building up an institutional capital.

For the assessment of these opposition generators under the real options approach, some models proposed in studies related to regulatory policies in wind energy projects can be adapted, such as $[32,55,73,74,91,92,107,111,126]$; models that use the decision tree technique to assess real options: $[106,111,116,117,123,124]$, or those that use dynamic programming, such as [58,91].

Regarding the uncertainties explored in research with a real options approach, most were found to be random variables with continuous states that are discretized over time (price, cost, and wind speeds). However, there are several studies that assume uncertainties as random variables with discrete states at discrete times, modeled by Markov chains, which could be assimilated to model public opposition because they have similar characteristics: climate policy [115], policy changes related to the current support scheme [74], and long-term stochastic uncertainties in the restructured energy market, such as demand and the price of fuel [58].

Regarding the options to use, you can make use of options to invest now, postpone, or abandon $[91,92,111,116]$, and the same is true for the compound options, the one associated with rate change [126], or the one to either carry out, postpone, or abandon the investment before continuing with the next stage $[86,107,115,122]$.

From the analysis of public opposition, it follows that, in order to propose flexible strategies, the perception of the community must first be known; then, it must be determined what alternatives are available from the beginning and when these would be presented, based on consumer preferences.

Given that, despite an exhaustive search in the literature, no studies that included uncertainties, such as public opposition, modeled with current techniques was found, and, therefore, it is not known how people will react, so there is a gap that would be interesting to address, to assess flexibility when this type of uncertainty arises through the real options approach.

\section{Conclusions}

This article provides a review of models or approaches used in the evaluation of investment in wind systems, under uncertainty. In total, 97 publications were analyzed, finding that this type of research has been increasing. The real options approach is the one most used by researchers, applied in 31 publications, representing $32 \%$.

Twenty-eight sources of uncertainty were identified, which were grouped into nine categories: 1. Power generation, 2. Environmental conditions, 3. Energy price, 4. Costs, 5. Income, 6. Energy policies regulation, 7. Market, 8. Wind conditions, and 9. Technological progress. The price of electricity is the source of uncertainty that generates the most interest in the researchers, considered in 20 publications.

Random and non-random techniques or models are applied, both to value real options and in uncertainty modeling. 
There are a series of barriers to investment in wind power generation projects, within these are public opposition-NIMBY "Not in my backyard", but no studies were found under the real options approach that would develop this theme, which justifies the possibility of exploring what the management of flexibility may be in this case.

Given the importance of investment projects in renewable energy, including wind energy, flexibility is a key factor in the business decision-making process, both in the planning and operating phases. The organizations that have some level of managerial flexibility (administrative and operational) are able to adjust their current decisions to the changes and conditions generated in the future, as caused by the existence of uncertainty. Thus, flexibility becomes an alternative to face uncertainty, because it represents rights and opportunities that any organization can execute when the underlying conditions of a respective project are either favorable or unfavorable. When the value of flexibility is positive, it increases the value of investment cash flows, generating greater social welfare.

The effective use of renewable energy sources, including wind energy, is the best strategy to contribute to meeting the objectives of the 2030 Agenda and the Paris agreement, aimed at reducing $\mathrm{CO}_{2}$ emissions. For this reason, it is necessary to intensify in the future the level of research on investment in renewable energy projects, under the approach of real options, which allows further assessment of the uncertainty of the projects to establish flexible strategies and establish efficient controls on high risk of the project investment. According to the findings observed in this analysis, the following lines of future research identified others:

1. Within a framework of Real Options, investigate the decision of communities to invest in wind energy [72].

2. Delve into how the application of the real options approach has the potential to increase the expected value of the investment in wind energy, by addressing the impact of uncertainty in the evaluation of the wind resource and contemplating the flexibility within the design and in the project planning [113].

3. Deepen the impact of the uncertainty caused in the future development of regulatory policies for the generation of renewable energy [114].

4. Investigate the impact of additional, sequential, or staged investment options at the optimal investment time and size.

Future investigations related to public opposition:

1. Develop studies that consider the real options approach to evaluate the impact of public opposition on investment in renewable energy projects.

2. Study on how to create institutional capital for wind energy and other renewable resources. This implies that more participatory planning practices and inclusive politics of the communities are needed [153].

3. Research aimed at establishing the determinants for indigenous and Afro-descendant communities within their uses and custom to accept the location of renewable energy projects [155].

Author Contributions: Conceptualization, A.H.; methodology, B.M., L.G. and A.H.; validation, A.H. and L.G.; formal analysis, B.M.; investigation, B.M.; resources, B.M.; data curation, A.H. and L.G.; writing—original draft preparation, B.M.; writing—review and editing, A.H. and L.G.; supervision, A.H., L.G.; funding acquisition, B.M. All authors have read and agreed to the published version of the manuscript.

Funding: This research was funded by the departmento de La Guajira-Colombia, through the project: Master's and Doctoral Studies inside and outside the Country for Professionals in the departamento de La Guajira- BPIN 2013000100032, with resources of Direct Allocation of Royalties, granted through the agreement of Condonable Educational Credit PFAN 019 of 2015, executed by the "Universidad de La Guajira"; and the "Universidad del Norte".

Institutional Review Board Statement: Not applicable.

Informed Consent Statement: Not applicable. 


\section{Data Availability Statement: Not applicable.}

Conflicts of Interest: The authors declare no conflict of interest.

\section{References}

1. Harjanne, A.; Korhonen, J.M. Abandoning the concept of renewable energy. Energy Policy 2019, 127, 330-340. [CrossRef]

2. Mentis, D.; Howells, M.; Rogner, H.; Korkovelos, A.; Arderne, C. Lighting the World: The first application of an open source, spatial electrification tool (OnSSET) on Sub-Saharan Africa Lighting the World: The first application of an open source, spatial electrification tool (OnSSET) on Sub-Saharan Africa. Environ. Res. Lett. 2017, 12, 085003. [CrossRef]

3. Lehne, K.-H. Informe Especial: Emisiones de Gases de Efecto Invernadero en la UE: Se Notifican Correctamente, Pero es Necesario Tener un Mayor Conocimiento de las Futuras Reducciones. 2019. Available online: https://www.eca.europa.eu/es/Pages/ DocItem.aspx?did=51834 (accessed on 12 July 2021).

4. GWEC. Global Wind Report I Gwec; Globle Wind Energy Counc.: Brussels, Belgium, 2021; p. 75.

5. Ministerio de Minas y Energía. La Transición Energética de Colombia; Ministerio de Minas y Energía: Bogotá, Colombia, 2020.

6. Kordmahaleh, A.A.; Naghashzadegan, M.; Javaherdeh, K.; Khoshgoftar, M. Design of a 25 MWe Solar Thermal Power Plant in Iran with Using Parabolic Trough Collectors and a Two-Tank Molten Salt Storage System. Int. J. Photoenergy 2017, 2017. [CrossRef]

7. Deutch, J. Decoupling Economic Growth and Carbon Emissions. Joule 2017, 1, 3-5. [CrossRef]

8. Zafar, R.; Mahmood, A.; Razzaq, S.; Ali, W.; Naeem, U.; Shehzad, K. Prosumer based energy management and sharing in smart grid. Renew. Sustain. Energy Rev. 2018, 82, 1675-1684. [CrossRef]

9. Fernandes, B.; Cunha, J.; Ferreira, P. The use of real options approach in energy sector investments. Renew. Sustain. Energy Rev. 2011, 15, 4491-4497. [CrossRef]

10. Burke, M.J.; Stephens, J.C. Energy Research \& Social Science Political power and renewable energy futures: A critical review. Energy Res. Soc. Sci. 2018, 35, 78-93.

11. IRENA. Renewable Capacity Statistics 2021. 2021. Available online: https://www.irena.org/publications/2021/March/ Renewable-Capacity-Statistics-2021 (accessed on 25 July 2021).

12. Bolinger, M.; Wiser, R. Wind power price trends in the United States: Struggling to remain competitive in the face of strong growth. Energy Policy 2009, 37, 1061-1071. [CrossRef]

13. Mengal, A.; Uqaili, M.A.; Harijan, K.; Memon, A.G. Competitiveness of wind power with the conventional thermal power plants using oil and natural gas as fuel in Pakistan. Energy Procedia 2014, 52, 59-67. [CrossRef]

14. Astariz, S.; Iglesias, G. Enhancing wave energy competitiveness through co-located wind and wave energy farms. A review on the shadow effect. Energies 2015, 8, 7344-7366. [CrossRef]

15. Albadi, M.H.; El-Saadany, E.F. Overview of wind power intermittency impacts on power systems. Electr. Power Syst. Res. 2010, 80, 627-632. [CrossRef]

16. Notton, G.; Nivet, M.L.; Voyant, C.; Paoli, C.; Darras, C.; Motte, F.; Fouilloy, A. Intermittent and stochastic character of renewable energy sources: Consequences, cost of intermittence and benefit of forecasting. Renew. Sustain. Energy Rev. 2018, 87, 96-105. [CrossRef]

17. Baagøe-Engels, V.; Stentoft, J. Operations and maintenance issues in the offshore wind energy sector. Int. J. Energy Sect. Manag. 2016, 10, 245-265. [CrossRef]

18. Peeters, C.; Guillaume, P.; Helsen, J. Vibration-based bearing fault detection for operations and maintenance cost reduction in wind energy. Renew. Energy 2018, 116, 74-87. [CrossRef]

19. Ayodele, T.R.; Jimoh, A.; Munda, J.L.; Agee, J.T. Challenges of grid integration of wind power on power system grid integrity: A review. Int. J. Renew. Energy Res. 2012, 2, 618-626.

20. Yuan, X.; Cheng, S.; Wen, J. Prospects analysis of energy storage application in grid integration of large-scale wind power. Dianli Xitong Zidonghua Autom. Electr. Power Syst. 2013, 37, 14-18.

21. Saidur, R.; Islam, M.R.; Rahim, N.A.; Solangi, K.H. A review on global wind energy policy. Renew. Sustain. Energy Rev. 2010, 14, 1744-1762. [CrossRef]

22. Leung, D.Y.C.; Yang, Y. Wind energy development and its environmental impact: A review. Renew. Sustain. Energy Rev. 2012, 16, 1031-1039. [CrossRef]

23. Saidur, R.; Rahim, N.A.; Islam, M.R.; Solangi, K.H. Environmental impact of wind energy. Renew. Sustain. Energy Rev. 2011, 15, 2423-2430. [CrossRef]

24. IREA; IRENA. Future of Wind Deployment, Investment, Technology, Grid Integration and Socio-Economic Aspects. 2019. Available online: https://www.irena.org/_/media/files/irena/agency/publication/2019/oct/irena_future_of_wind_2019.pdf (accessed on 26 July 2021).

25. Presidencia de la República de Colombia. Decreto 2164 de 1995. D. Of. 1995, 1995, 12. Available online: https:/ /www.mininterior. gov.co/la-institucion/normatividad/decreto-2164-de-1995 (accessed on 19 June 2021).

26. Congreso de Colombia. Ley 21 de 1991: Convenio 169. Convenio sobre Pueblos Indígenas y Tribales en Países Independientes. D. Of. 1991, p. 14. Available online: http://www.urosario.edu.co/jurisprudencia/catedra-viva-intercultural/Documentos/ley_ 21_91.pdf (accessed on 8 June 2021).

27. Aitken, M.; Haggett, C.; Rudolph, D. Wind farms community engagement: Good practice review. Edinb. Clim. 2014, 1-103. Available online: https:/ / core.ac.uk/download/pdf/84000113.pdf (accessed on 15 June 2021). 
28. Ledec, G.C.; Rapp, K.W.; Aiello, R.G. Greening the Wind; World Bank Publications: Washington, DC, USA, 2011. [CrossRef]

29. Munday, M.; Bristow, G.; Cowell, R. Wind farms in rural areas: How far do community benefits from wind farms represent a local economic development opportunity? J. Rural Stud. 2011, 27, 1-12. [CrossRef]

30. Hernando, A.; Razmilic, S.; Jiménez, S.; Katz, R.; Martínez, D. Puntos de referencia: [Editorial]. Rev. ADM 2017, $282-284$.

31. Kinias, I.; Tsakalos, I.; Konstantopoulos, N. Investment evaluation in renewable projects under uncertainty, using real options analysis: The case of wind power industry. Investig. Manag. Financ. Innov. 2020, 14, 96-103. [CrossRef]

32. Detemple, J.; Kitapbayev, Y. The value of green energy under regulation uncertainty. Energy Econ. 2020, 89, 104807. [CrossRef]

33. Krömer, S. Model risk regarding monthly wind energy production for the valuation of a wind farm investment. Int. J. Energy Sect. Manag. 2019, 13, 862-884. [CrossRef]

34. Nasrolahpour, E.; Zareipour, H.; Rosehart, W.D. Battery investment by a strategic wind producer: A scenario-based decomposition approach. Electr. Power Syst. Res. 2020, 182, 106255. [CrossRef]

35. Oh, E.; Son, S. Theoretical energy storage system sizing method and performance analysis for wind power forecast uncertainty management. Renew. Energy 2020, 155, 1060-1069. [CrossRef]

36. Ioannou, A.; Angus, A.; Brennan, F. Stochastic fi nancial appraisal of offshore wind farms. Renew. Energy 2020, 145, 1176-1191. [CrossRef]

37. Mehrjerdi, H.; Hemmati, R. Wind-hydrogen storage in distribution network expansion planning considering investment deferral and uncertainty. Sustain. Energy Technol. Assess. 2020, 39, 100687. [CrossRef]

38. Liu, R.; He, L.; Liang, X.; Yang, X.; Xia, Y. Is there any difference in the impact of economic policy uncertainty on the investment of traditional and renewable energy enterprises?-A comparative study based on regulatory effects. J. Clean. Prod. 2020, 255, 120102. [CrossRef]

39. Chowdhury, N.; Pilo, F.; Pisano, G. Optimal Energy Storage System Positioning and Sizing with Robust Optimization. Energies 2020, 13, 512. [CrossRef]

40. Tan, J.; Wu, Q.; Hu, Q.; Wei, W.; Liu, F.; Eb, C.H.P. Adaptive robust energy and reserve co-optimization of integrated electricity and heating system considering wind uncertainty. Appl. Energy 2020, 260, 114230. [CrossRef]

41. Zhan, S.; Hou, P.; Enevoldsen, P.; Yang, G.; Zhu, J.; Eichman, J.; Jacobson, M.Z. Electrical Power and Energy Systems Co-optimized trading of hybrid wind power plant with retired EV batteries in energy and reserve markets under uncertainties. Electr. Power Energy Syst. 2020, 117, 105631. [CrossRef]

42. Verleysen, K.; Coppitters, D.; Parente, A.; De Paepe, W.; Contino, F. How can power-to-ammonia be robust ? Optimization of an ammonia synthesis plant powered by a wind turbine considering operational uncertainties. Fuel 2020, 266, 117049. [CrossRef]

43. Yang, G.; Jiang, Y.; You, S. Planning and operation of a hydrogen supply chain network based on the off-grid wind-hydrogen coupling system. Int. J. Hydrogen Energy 2020, 45, 20721-20739. [CrossRef]

44. Al, A.; Sirjani, R.; Daneshvar, S. New hybrid probabilistic optimisation algorithm for optimal allocation of energy storage systems considering correlated wind farms. J. Energy Storage 2020, 29, 101335.

45. Hübler, C.; Piel, J.; Stetter, C.; Gebhardt, C.G.; Breitner, M.H.; Rolfes, R. In fl uence of structural design variations on economic viability of offshore wind turbines: An interdisciplinary analysis. Renew. Energy 2020, 145, 1348-1360. [CrossRef]

46. Ge, L.; Zhang, S.; Bai, X.; Yan, J.; Shi, C.; Wei, T. Optimal Capacity Allocation of Energy Storage System considering Uncertainty of Load and Wind Generation. Math. Probl. Eng. 2020, 2020, 2609674. [CrossRef]

47. Yang, H.; Yu, Q.; Liu, J.; Jia, Y.; Yang, G.; Ackom, E.; Dong, Z.Y. Optimal Wind-Solar Capacity Allocation with Coordination of Dynamic Regulation of Hydropower and Energy Intensive Controllable Load. IEEE Access 2020, 8, 110129-110139. [CrossRef]

48. Kong, L.; Li, Z.; Liang, L.; Xia, Y.; Xie, J. A capacity-investment model of wind power with uncertain supply-price under high penetration rate. J. Clean. Prod. 2020, 178, 917-926. [CrossRef]

49. Keck, R.; Sondell, N. Validation of uncertainty reduction by using multiple transfer locations for WRF-CFD coupling in numerical wind energy assessments. Wind Energy Sci. 2020, 5, 997-1005. [CrossRef]

50. Stetter, C.; Piel, J.; Hamann, J.F.H.; Breitner, M.H. Competitive and risk-adequate auction bids for onshore wind projects in Germany. Energy Econ. 2020, 90, 104849. [CrossRef]

51. Abdalla, O.H.; Smieee, L.; Adma, M.A.A.; Ahmed, A.S. Two-stage robust generation expansion planning considering long- and short-term uncertainties of high share wind energy. Electr. Power Syst. Res. 2020, 189, 106618. [CrossRef]

52. Henckes, P.; Frank, C.; Küchler, N.; Peter, J.; Wagner, J. Uncertainty estimation of investment planning models under high shares of renewables using reanalysis data. Energy 2020, 208, 118207. [CrossRef]

53. ANiromandfam, A.; Movahedi, A.; Zarezadeh, E. Virtual energy storage modeling based on electricity customers' behavior to maximize wind profit. J. Energy Storage 2020, 32, 101811. [CrossRef]

54. Zhou, J.; Wu, Y.; Dong, H.; Tao, Y.; Xu, C. Proposal and comprehensive analysis of gas-wind-photovoltaic- hydrogen integrated energy system considering multi-participant interest preference. J. Clean. Prod. 2020, 265, 121679. [CrossRef]

55. Zhao, X.; Yao, J.; Sun, C.; Pan, W. Impacts of carbon tax and tradable permits on wind power investment in China. Renew. Energy 2019, 135, 1386-1399. [CrossRef]

56. Maeda, M.; Watts, D. The unnoticed impact of long-term cost information on wind farms' economic value in the USA-A real option analysis. Appl. Energy 2019, 241, 540-547. [CrossRef]

57. Vavatsikos, A.P.; Arvanitidou, A.; Petsas, D. Wind farm investments portfolio formation using GIS-based suitability analysis and simulation procedures. J. Environ. Manag. 2019, 252, 109670. [CrossRef] 
58. Askari, M.T.; Zainal, M.; Ab, A.; Tahmasebi, M.; Bolandifar, E. Modeling optimal long-term investment strategies of hybrid wind-thermal companies in restructured power market. J. Mod. Power Syst. Clean Energy 2019, 7, 1267-1279. [CrossRef]

59. Abdulgalil, M.A.; Khalid, M.; Alismail, F. Optimal Sizing of Battery Energy Storage for a Grid-Connected Microgrid Subjected to Wind Uncertainties. Energies 2019, 12, 2412. [CrossRef]

60. Junior, P.R.; Fischetti, E.; Araújo, V.G.; Peruchi, R.S.; Aquila, G.; Rocha Luiz, C.; Lacerda, L.S. Wind Power Economic Feasibility under Uncertainty and the Application of ANN in Sensitivity Analysis. Energies 2019, 12, 2281. [CrossRef]

61. Abdulgalil, M.; Khalid, M.; Alismail, F. Optimizing a Distributed Wind-Storage System Under Critical Uncertainties Using Benders Decomposition. IEEE Access 2019, 7, 77951-77963. [CrossRef]

62. Li, Y.; Wang, J.; Gu, C.; Liu, J.; Li, Z. Investment optimization of grid-scale energy storage for supporting different wind power utilization levels. J. Mod. Power Syst. Clean Energy 2019, 7, 1721-1734. [CrossRef]

63. Pizarro-alonso, A.; Ravn, H.; Münster, M. Uncertainties towards a fossil-free system with high integration of wind energy in long-term planning. Appl. Energy 2019, 253, 113528. [CrossRef]

64. Yan, J.; Zhang, H.; Liu, Y.; Han, S.; Li, L. Uncertainty estimation for wind energy conversion by probabilistic wind turbine power curve modelling. Appl. Energy 2019, 239, 1356-1370. [CrossRef]

65. Tagliapietra, S.; Zachmann, G.; Fredriksson, G. Estimating the cost of capital for wind energy investments in Turkey. Energy Policy 2019, 131, 295-301. [CrossRef]

66. Van Thang, V.; Trung, N.H. Evaluating efficiency of renewable energy sources in planning micro-grids considering uncertainties. J. Energy Syst. 2019, 3, 14-25. [CrossRef]

67. Quan, N.; Kim, H.M. Greedy robust wind farm layout optimization with feasibility guarantee feasibility guarantee. Eng. Optim. 2019, 51, 1152-1167. [CrossRef]

68. Mora, E.B.; Spelling, J.; van der Weijde, A.H.; Pavageau, E.M. The effects of mean wind speed uncertainty on project finance debt sizing for offshore wind farms. Appl. Energy 2019, 252, 113419. [CrossRef]

69. Fuchs, C.; Marquardt, K.; Kasten, J.; Skau, K. Wind Turbines on German Farms-An Economic Analysis. Energies 2019, $12,1587$. [CrossRef]

70. Zhang, Y.; Wang, L.; Wang, N.; Duan, L.; Zong, Y.; You, S.; Marechal, F.; Yang, Y. Balancing wind-power fluctuation via onsite storage under uncertainty: Power-to-hydrogen-to-power versus lithium battery. Renew. Sustain. Energy Rev. 2019, 116, 109465. [CrossRef]

71. Ioannou, A.; Angus, A.; Brennan, F. Informing parametric risk control policies for operational uncertainties of o ff shore wind energy assets. Ocean Eng. 2019, 177, 1-11. [CrossRef]

72. Ribeiro, A.; Finotti, F.; Perobelli, C.; Baumgratz, A. Counterfactual comparisons of investment options for wind power and agricultural production in the United States: Lessons from Northern Ohio. Energy Econ. 2018, 74, $299-309$.

73. Finjord, F.; Hagspiel, V.; Lavrutich, M.; Tangen, M. The impact of Norwegian-Swedish green certificate scheme on investment behavior: A wind energy case study. Energy Policy 2018, 123, 373-389. [CrossRef]

74. Dalby, P.A.O.; Gillerhaugen, G.R.; Hagspiel, V.; Leth-olsen, T.; Thijssen, J.J.J. Green investment under policy uncertainty and Bayesian learning. Energy 2018, 161, 1262-1281. [CrossRef]

75. Li, Y.; Wu, M.; Li, Z. A Real Options Analysis for Renewable Energy Investment Decisions under China Carbon Trading Market. Energies 2018, 11, 1817. [CrossRef]

76. Gazheli, A.; Van Den Bergh, J. Real options analysis of investment in solar vs. wind energy: Diversi fi cation strategies under uncertain prices and costs. Renew. Sustain. Energy Rev. 2018, 82, 2693-2704. [CrossRef]

77. Romanuke, V. Wind Farm Energy and Costs Optimization Algorithm under Uncertain Parameters of Wind Speed Distribution. Stud. Inform. Control 2018, 27, 155-164. [CrossRef]

78. Yu, Y.; Wen, X.; Zhao, J.; Xu, Z.; Li, J. Co-Planning of Demand Response and Distributed Generators in an Active Distribution Network. Energies 2018, 11, 354. [CrossRef]

79. Aaboud, M.; Aad, G.; Abbott, B.; Abeloos, B.; Abidi, S.H.; AbouZeid, O.S.; Abraham, N.L.; Abramowicz, H.; Abreu, H.; Abreu, R.; et al. Search for dark matter and other new phenomena in events with an energetic jet and large missing transverse momentum using the ATLAS detector. J. High Energy Phys. 2018, 2018, 1-53. [CrossRef]

80. Valinejad, J.; Marzband, M.; Funsho Akorede, M.; DElliott, I.; Godina, R.; Matias, J.C.; Pouresmaeil, E. Long-Term Decision on Wind Investment with Considering Different Load Ranges of Power Plant for Sustainable Electricity Energy Market. Sustainability 2018, 10, 3811. [CrossRef]

81. Jiang, X.; Nan, G.; Liu, H.; Guo, Z.; Zeng, Q.; Jin, Y. Optimization of Battery Energy Storage System Capacity for Wind Farm with Considering Auxiliary Services Compensation. Appl. Sci. 2018, 8, 1957. [CrossRef]

82. Deshmukh, R.; Mileva, A.; Wu, G.C. Renewable energy alternatives to mega hydropower: A case study of Inga 3 for Southern Africa. Environ. Res. Lett. 2018, 13, 064020. [CrossRef]

83. Li, Z.; Wang, C.; Li, B.; Wang, J.; Zhao, P.; Zhu, W.; Yang, M.; Ding, Y. Probability-interval-based optimal planning of integrated energy system with uncertain wind power. IEEE Trans. Ind. Appl. 2018, 56, 4-13. [CrossRef]

84. Ioannou, A.; Angus, A.; Brennan, F. A lifecycle techno-economic model of offshore wind energy for di ff erent entry and exit instances. Appl. Energy 2018, 221, 406-424. [CrossRef]

85. Esmaieli, M.; Ahmadian, M. The effect of research and development incentive on wind power investment, a system dynamics approach. Renew. Energy 2018, 126, 765-773. [CrossRef] 
86. Kristiansen, M.; Svendsen, H.G.; Korpas, M.; Fleten, S.-E. Multistage grid investments incorporating uncertainty in offshore wind development. Energy Procedia 2017, 137, 468-476. [CrossRef]

87. Jannati, J.; Yazdaninejadi, A.; Talavat, V. Simultaneous Planning of Renewable/Non-Renewable Distributed Generation Units and Energy Storage Systems in Distribution Networks. Trans. Electr. Electron. Mater. 2017, 18, 111-118. [CrossRef]

88. Chen, L.; Macdonald, E. Wind Farm Layout Sensitivity Analysis and Probabilistic Model of Landowner Decisions. J. Energy Resour. Technol. 2017, 139, 031202. [CrossRef]

89. Hamoudi, H.; Maule, I. Photovoltaic and wind cost decrease estimation: Implications for investment analysis. Energy 2017, 137, 1054-1065.

90. Aquila, G.; Rotela, P.; de Oliveira, E.; de Queiroz, A. Wind power feasibility analysis under uncertainty in the Brazilian electricity market. Energy Econ. 2017, 65, 127-136. [CrossRef]

91. Eryilmaz, D.; Homans, F.R. How does uncertainty in renewable energy policy affect decisions to invest in wind energy? Electr. J. 2016, 29, 64-71. [CrossRef]

92. Kitzing, L.; Juul, N.; Drud, M.; Krogh, T. A real options approach to analyse wind energy investments under different support schemes. Appl. Energy 2016, 188, 83-96. [CrossRef]

93. Pazouki, S.; Haghifam, M. Optimal planning and scheduling of energy hub in presence of wind, storage and demand response under uncertainty. Int. J. Electr. Power Energy Syst. 2016, 80, 219-239. [CrossRef]

94. Lamadrid, A.J.; Maneevitjit, S.; Mount, T.D. The Economic Value of Transmission Lines and the Implications for Planning Models. Energy Econ. 2016, 57, 1-15. [CrossRef]

95. Caralis, G.; Chaviaropoulos, P.; Ruiz, V.; Diakoulaki, D.; Kotroni, V.; Lagouvardos, K.; Gao, Z. Lessons learnt from the evaluation of the feed-in tariff scheme for offshore wind farms in Greece using a Monte Carlo approach. J. Wind Eng. Ind. Aerodyn. 2016, 157, 63-75. [CrossRef]

96. Werner, L.; Scholtens, B. Firm Type, Feed-in Tariff, and Wind Energy Investment in Germany: An Investigation of Decision Making Factors of Energy Producers Regarding Investing in Wind Energy Capacity. J. Ind. Ecol. 2016, 21, 402-411. [CrossRef]

97. Sjoerd, A.; Van Den Broek, M.; Özdemir, Ö.; Koutstaal, P.; Faaij, A. Business case uncertainty of power plants in future energy systems with wind power. Energy Policy 2016, 89, 237-256.

98. Xiao, Y.; Wang, X.; Wang, X.; Wu, Z. Trading wind power with barrier option. Appl. Energy 2016, 182, 232-242. [CrossRef]

99. Díaz, G.; Gómez-aleixandre, J.; Coto, J. Dynamic evaluation of the levelized cost of wind power generation. Energy Convers. Manag. 2015, 101, 721-729. [CrossRef]

100. Díaz, G.; Moreno, B.; Coto, J.; Gómez-aleixandre, J. Valuation of wind power distributed generation by using Longstaff-Schwartz option pricing method. Appl. Energy 2015, 145, 223-233. [CrossRef]

101. Fang, X.; Li, F.; Wei, Y.; Azim, R. Reactive Power Planning under High Penetration of Wind Energy using Benders Decomposition. IET Gener. Transm. Distrib. 2015, 9, 1835-1844. [CrossRef]

102. Seljom, P.; Tomasgard, A. Short-term uncertainty in long-term energy system models-A case study of wind power in Denmark Energy Econ. 2015, 49, 157-167. [CrossRef]

103. Hong, Y.; Lai, Y.; Chang, Y.; Lee, Y.; Liu, P. Optimizing Capacities of Distributed Generation and Energy Storage in a Small Autonomous Power System Considering Uncertainty in Renewables. Energies 2015, 8, 2473-2492. [CrossRef]

104. Siddons, C.; Allan, G.; Mcintyre, S. How accurate are forecasts of costs of energy? A methodological contribution. Energy Policy 2015, 87, 224-228. [CrossRef]

105. Rodríguez, O.; del Río, J.A.; Jaramillo, O.A.; Martínez, M. Wind Power Error Estimation in Resource Assessments. PLoS ONE 2015, 10, e0124830. [CrossRef]

106. Abadie, L.M.; Chamorro, J.M. Valuation of Wind Energy Projects: A Real Options Approach. Energies 2014, 7, $3218-3255$. [CrossRef]

107. Krogh, T.; Meade, N.; Fleten, S. Renewable energy investments under di ff erent support schemes: A real options approach. Eur. J. Oper. Res. 2012, 220, 225-237.

108. Correa, M.D.; Gomes, L.L.; Teixeira, L.E.B. Investors' asymmetric views and their decision to enter Brazil's wind energy sector. Pesqui. Oper. 2014, 34, 319-345.

109. Weibel, S.; Madlener, R. Cost-Effective Design of Ringwall Storage Hybrid Power Plants: A Real Options Analysis. Energy Procedia 2014, 61, 2196-2200. [CrossRef]

110. Serrano, J.; Burgos, M.; Riquelme, J. M Optimization of Wind Farm Turbine Layout Including Decision Making Under Risk; IEEE: Piscataway, NJ, USA, 2014.

111. Monjas-barroso, M.; Balibrea-Iniesta, J. Valuation of projects for power generation with renewable energy: A comparative study based on real regulatory options. Energy Policy 2013, 55, 335-352. [CrossRef]

112. Jin, S.; Botterud, A.; Ryan, S.M. Impact of Demand Response on Thermal Generation Investment with High Wind Penetration. IEEE Trans. Smart Grid 2013, 4, 2374-2383. [CrossRef]

113. Kaiser, M.J.; Snyder, B.F. Modeling offshore wind installation costs on the US Outer Continental Shelf. Renew. Energy 2013, 50, 676-691. [CrossRef]

114. Heinrich, W.; Szolgayová, J.; Fuss, S.; Obersteiner, M. Renewable energy investment: Policy and market impacts. Appl. Energy 2012, 97, 249-254. 
115. Heinrich, W.; Fuss, S.; Szolgayová, J.; Obersteiner, M. Investment in wind power and pumped storage in a real options model. Renew. Sustain. Energy Rev. 2012, 16, 2242-2248.

116. Martinez-cesena, E.A.; Member, S.; Mutale, J.; Member, S. Wind Power Projects Planning Considering Real Options for the Wind Resource Assessment. IEEE Trans. Sustain. Energy 2012, 3, 158-166. [CrossRef]

117. Ochoa, M.; Betancur, H.; David, J.; Múnera, G.; Mauricio, Ó. L a Valoración de Proyectos Bajo el Enfoque de Opciones. 2012. Available online: https:/ / www.redalyc.org/pdf/205/20523152009.pdf (accessed on 17 July 2021).

118. Al-yahyai, S.; Charabi, Y.; Al-badi, A.; Gastli, A. Nested ensemble NWP approach for wind energy assessment. Renew. Energy 2012, 37, 150-160. [CrossRef]

119. Lee, S. Using real option analysis for highly uncertain technology investments: The case of wind energy technology. Renew. Sustain. Energy Rev. 2011, 15, 4443-4450. [CrossRef]

120. Dicorato, M.; Forte, G.; Pisani, M.; Trovato, M. Guidelines for assessment of investment cost for offshore wind generation. Renew. Energy 2011, 36, 2043-2051. [CrossRef]

121. Barradale, M.J. Impact of public policy uncertainty on renewable energy investment: Wind power and the production tax credit. Energy Policy 2010, 38, 7698-7709. [CrossRef]

122. Méndez, M.; Goyanes, A.; Lamothe, P. Real Options Valuation of a Wind Farm. February 2009. Available online: http: / / www.realoptions.org/papers2009/46.pdf (accessed on 24 July 2021).

123. Muñoz, J.I.; Contreras, J.; Caamaño, J.; Correia, P.F.; Carlo, M. Risk Assessment of Wind Power Generation Project Investments based on Real Options. In 2009 IEEE Bucharest PowerTech; IEEE: Piscataway, NJ, USA, 2009; pp. 1-8.

124. Dykes, K.; de Neufville, R. Real options for a wind farm in Wapakoneta, Ohio: Incorporating uncertainty into economic feasibility studies for community wind. In Proceedings of the Paper submitted for the World Wind Energy Conference of 2008, Kingston, ON, Canada, 24-26 June 2007.

125. Magnus, K.; Fleten, S.; Maribu, K.M.; Wangensteen, I. Optimal investment strategies in decentralized renewable power generation under uncertainty. Energy 2007, 32, 803-815.

126. Yu, W.; Sheblé, G.B.; Lopes, J.A.P.; Matos, M.A. Valuation of switchable tariff for wind energy. Electr. Power Syst. Res. 2006, 76, 382-388. [CrossRef]

127. Aponte, R.; Muñoz, F.; Álzate, L. La Evaluación Financiera De Proyectos Y Su Aporte En La Generación De Valor Corporativo. Cienc. Y Poder Aéreo 2017, 12, 144-155. [CrossRef]

128. Santos, L.; Soares, I.; Mendes, C.; Ferreira, P. Real options versus traditional methods to assess renewable energy projects. Renew. Energy 2014, 68, 588-594. [CrossRef]

129. González, Y.; Zuluaga, M.; Maya, C. El Valor de la Propiedad Industrial Aproximación a un Método de Valoración Financiera de Activos Intangibles; Universidad EAFIT: Medellín, Colombia, 2010.

130. Attoh-Okine, N.O.; Ayyub, B.M. Applied Research in Uncertainty Modeling and Analysis; Springer: New York, NY, USA, 2005.

131. Conejo, A.J.; Carrión, M.; Morales, J.M. Decision Making under Uncertainty in Electricity Markets; Springer: New York, NY, USA, 2010; Volume 1.

132. Dixit, R.K.; Pindyck, R.S. Investment under Uncertainty; Princeton University Press: Princeton, NJ, USA, 1994.

133. Cuervo, F.I.; Botero, S.B. Aplicación de las opciones reales en la toma de decisiones en los mercados de electricidad. Estud. Gerenc. 2014, 30, 397-407. [CrossRef]

134. Guerequeta, R.; Vallecillo, A. Técnicas de Diseño de Algorismos. 2000. Available online: https://archive.org/details/ TecnicasDiseoAlgoritmosGuequeretaYVallecillo (accessed on 28 July 2021).

135. Black, F.; Scholes, M. The pricing of options and corporate liabilities. J. Political Econ. 1973, 81, 637-654. [CrossRef]

136. Merton, R.C. Theory of rational option pricing. Bell J. Econ. Manag. Sci. 1973, 4, 141-183. [CrossRef]

137. Mascareñas, J. Opciones Reales y Valoración de Activos: Como Medir la Flexibilidad Operativa en la Empresa; Prentice Hall: Hoboken, NJ, USA, 2004.

138. Ferreira, N.; Kar, J.; Trigeorgis, L. Option Games. Harv. Bus. Rev. 2009, 87, 101-107.

139. Kozlova, M. Real option valuation in renewable energy literature: Research focus, trends and design. Renew. Sustain. Energy Rev. 2017, 80, 180-196. [CrossRef]

140. Boyle, P.P. Options: A Monte Carlo approach. J. Financ. Econ. 1977, 4, 323-338. [CrossRef]

141. Kodukula, P.; Papudesu, C. Project Valuation Using Real Options: A Practitioner's Guide; J. Ross Publishing: Fort Lauderdale, FL, USA, 2006.

142. Morrison, S. Nested Simulation for Economic Capital. Barrie + hibbert. 2009. Available online: www.barrhibb.com (accessed on 22 July 2021).

143. Longstaff, F.A.; Schwartz, E.S. Valuing American Options by Simulation: A Simple Least-Squares Approach. Rev. Financ. Stud. 2001, 14, 113-147. [CrossRef]

144. Yang, X.-S. Nature-Inspired Algorithms and Applied Optimization; Springer: New York, NY, USA, 2018.

145. Mosiño, A.; Salomón-Núñez, L.A.; Moreno-Okuno, A.T. Estudio empírico sobre el tipo de cambio. Econoquantum 2019, $16,33-56$. [CrossRef]

146. Pindyck, R.S. The dynamics of commodity spot and futures markets: A primer. Energy J. 2001, 22. [CrossRef]

147. Vveinhardt, J.; Streimikiene, D.; Rizwan, A.R.; Nawaz, A.; Rehman, A. Mean reversion: An investigation from Karachi stock exchange sectors. Technol. Econ. Dev. Econ. 2016, 22, 493-511. [CrossRef] 
148. Gujarati, D.N.; Porter, D.C. Econometria Básica, 4th ed.; Editora Campus: São Paulo, Brasil, 2006.

149. Góngora, D.A.; Azumendi, D. Predicción de la Velocidad del Viento para la Estimación de la Energía Generada por un Aerogenerador; Uniandes: Bogotá, Colombia, 2018.

150. Quevedo, F. Distribución normal. Medwave 2011, 1-5. [CrossRef]

151. Latiff, A. La “Curva de Aprendizaje”. Qué es y cómo se mide. Rev. Urol. Colomb. 2005, XIV, 15-17.

152. Silva, P.P.B.; Riveros, D.P.B.; Naranjo, C.J. Aplicación de la lúdica en la curva de aprendizaje. Sci. Et Tech. 2005, 1, 185-190.

153. Wolsink, M. Wind power and the NIMBY-myth: Institutional capacity and the limited significance of public support. Renew. Energy 2000, 21, 49-64. [CrossRef]

154. Wolsink, M. Wind power implementation: The nature of public attitudes: Equity and fairness instead of "backyard motives". Renew. Sustain. Energy Rev. 2007, 11, 1188-1207. [CrossRef]

155. Wüstenhagen, R.; Wolsink, M.; Bürer, M.J. Social acceptance of renewable energy innovation: An introduction to the concept. Energy Policy 2007, 35, 2683-2691. [CrossRef]

156. Buijs, P.; Bekaert, D.; Cole, S.; Van Hertem, D.; Belmans, R. Transmission investment problems in Europe: Going beyond standard solutions. Energy Policy 2011, 39, 1794-1801. [CrossRef]

157. Khademi, E.; Timmermans, H.; Borgers, A. Temporal adaptation to reward schemes: Results of the spitsscoren project. Transp. Res. Procedia 2014, 3, 60-69. [CrossRef]

158. Jung, N.; Moula, M.E.; Fang, T.; Hamdy, M.; Lahdelma, R. Social acceptance of renewable energy technologies for buildings in the Helsinki Metropolitan Area of Finland. Renew. Energy 2016, 99, 813-824. [CrossRef] 